\title{
Localized scleroderma (morphea). Diagnostic and therapeutic recommendations of the Polish Dermatological Society
}

\section{Twardzina ograniczona (morphea). Rekomendacje diagnostyczno-terapeutyczne Polskiego Towarzystwa Dermatologicznego}

Dorota Krasowska', Lidia Rudnicka², Aleksandra Dańczak-Pazdrowska33, Grażyna Chodorowska', Anna Woźniacka4, Anna Lis-Święty ${ }^{5}$, Joanna Czuwara², Joanna Maj', Sławomir Majewski ${ }^{7}$, Anna Sysa-Jędrzejowska ${ }^{4}$, Anna Wojas-Pelc ${ }^{8}$

\author{
'Department of Dermatology, Venereology and Paediatric Dermatology, Medical University of Lublin, Poland \\ 2Department of Dermatology, Medical University of Warsaw, Poland \\ 3Department of Dermatology, Poznan University of Medical Science, Poland \\ ${ }^{4}$ Department of Dermatology and Venereology, Medical University of Lodz, Poland \\ ${ }^{5}$ Department of Dermatology, Medical University of Silesia, Katowice, Poland \\ ${ }^{6}$ Department of Dermatology, Venereology and Allergology, Wroclaw Medical University, Poland \\ ${ }^{7}$ Department of Dermatology and Venereology, Medical University of Warsaw, Poland \\ ${ }^{8}$ Department of Dermatology, Medical College Jagiellonian University, Krakow, Poland \\ IKatedra i Klinika Dermatologii, Wenerologii i Dermatologii Dziecięcej Uniwersytetu Medycznego w Lublinie, Polska \\ 2Katedra i Klinika Dermatologiczna Warszawskiego Uniwersytetu Medycznego, Polska \\ ${ }^{3}$ Katedra i Klinika Dermatologii Uniwersytetu Medycznego w Poznaniu, Polska \\ ${ }^{4}$ Katedra i Klinika Dermatologii i Wenerologii Uniwersytetu Medycznego w Łodzi, Polska \\ ${ }^{5}$ Katedra i Klinika Dermatologii Śląskiego Uniwersytetu Medycznego w Katowicach, Polska \\ ${ }^{6}$ Katedra i Klinika Dermatologii, Wenerologii i Alergologii Uniwersytetu Medycznego we Wrocławiu, Polska \\ ${ }^{7}$ Katedra i Klinika Dermatologii i Wenerologii Warszawskiego Uniwersytetu Medycznego, Polska \\ ${ }^{8}$ Katedra i Klinika Dermatologii Uniwersytetu Jagiellońskiego Collegium Medicum w Krakowie, Polska
}

CORRESPONDING AUTHOR/ ADRES DO KORESPONDENCJI: prof. dr hab. Dorota Krasowska Katedra i Klinika Dermatologii, Wenerologii i Dermatologii Dziecięcej Uniwersytet Medyczny w Lublinie

ul. Staszica 16

20-081 Lublin e-mail: dor.krasowska@gmail.com

\begin{abstract}
Localized scleroderma (morphea) is a chronic autoimmune disease of the connective tissue. Its etiopathogenesis is unknown. Most often the disease affects the skin, but may also involve the subcutis, muscles, and the osteoarticular system. The clinical presentation and the course of disease may be diverse. This article presents clinical characteristics of various types of the disease, the classification of its subtypes, recommendations for differential diagnosis and treatment.
\end{abstract}

\section{STRESZCZENIE}

Twardzina ograniczona (morphea) jest przewlekłą chorobą zapalną tkanki łącznej o podłożu autoimmunologicznym i o niewyjaśnionej etiopatogenezie. Najczęściej zajęta jest skóra, ale proces chorobowy może zajmować tkankę podskórną, mięśnie i układ kostno-stawowy. Zróżnicowany obraz kliniczny choroby wymaga prawidłowego rozpoznania i zastosowania odpowiedniej terapii. W artykule przedstawiono charakterystykę kliniczną oraz zalecenia dotyczące klasyfikacji, postępowania diagnostycznego i leczenia.

Key words: localized scleroderma, classification, clinical picture, treatment.

Słowa kluczowe: twardzina ograniczona, klasyfikacja, obraz kliniczny, leczenie. 


\section{INTRODUCTION}

Localized scleroderma (LoSc, morphea) is a chronic, inflammatory and autoimmune disease of the connective tissue. Two peaks of incidence are observed, i.e. between the age of 7 and 11 in children, and 40 and 50 in adults; it occurs more frequently in women (2.6-6 times more often) [1-3]. Approximately 15\% of the patients are children below $10 \mathrm{y} / \mathrm{o}$ [4]. It is estimated that the LoSc incidence rate amounts to $0.4-2.7 / 100,000$ people/year [1].

Clinical picture of the LoSc is diverse and depends on activity, extent, depth, and evolution of lesions. The disease is usually diagnosed on the basis of a clinical picture, however, in case of any doubts, a biopsy for histopathological examination should be taken. LoSc forms involving superficial tissues have a tendency towards idiopathic remissions after several years and subside leaving dark red discolourations [5]. Severe cases involving deeper tissues require early diagnosis and introduction of a proper therapy. It is worth mentioning that on numerous occasions, proper disease diagnosis is delayed with several months or years [6]. The disease usually affects the skin, but may also involve the fasciae, muscles, and bones. Many papers emphasize the fact that depending on the clinical type of LoSc, extracutaneous manifestations may appear [3,6]. According to the current state of knowledge, LoSc does not progress into systemic sclerosis (SSc); however, it should be remembered that both diseases might co-exist $[1,5,7]$.

In 2018 Japanese Dermatological Association (JDA) proposed diagnostic criteria for LoSc that include: presence of local skin hardenings with well-defined edges, thickening, and homogenization of collagen bundles upon histopathological examination, and exclusion of other disease entities with a similar clinical picture (including systemic sclerosis, lichen sclerosus, keloids, and hypertrophic scars). A diagnosis of LoSc can be made when all of the above criteria are met [8].

\section{ETIOPATHOGENESIS}

Etiopathogenesis of LoSc has not been fully knows, and it is believes that the pathogenesis of this disease involves genetic, epigenetic, and environmental factors. Environmental factors seem to play a significant role in the pathogenesis of LoSc; there are known cases that LoSc-type lesions occurred due to mechanical injury, long-term pressure, and usage of drugs [5, 9-11]. The role of Borrelia burgdorferi spirochetes in the development of LoSc is debatable since there have been divergent reports published for a number of years $[1,5]$. At present, it is not recommended to determine the level of anti-B. burgdorferi

\section{WPROWADZENIE}

Twardzina ograniczona (morphea, localized scleroderma - LoSc) jest przewlekłą chorobą zapalną tkanki łącznej o podłożu autoimmunologicznym. Obserwuje się dwa szczyty zachorowań - między 7. a 11. rokiem życia u dzieci oraz między 40. a 50. rokiem życia u dorosłych; choroba występuje znacznie częściej u kobiet (2,6-6 razy częściej) [1-3]. Około 15\% chorych stanowią dzieci poniżej 10. roku życia [4]. Szacuje się, że zapadalność na LoSc wynosi 0,4-2,7/100 000 osób rocznie [1].

Obraz kliniczny LoSc jest zróżnicowany i zależy od aktywności, rozległości, głębokości i ewolucji zmian chorobowych. Rozpoznanie ustala się zwykle na podstawie obrazu klinicznego, jednak w każdym wątpliwym przypadku należy rozważyć pobranie wycinka do badania histopatologicznego. Postacie LoSc przebiegajace z zajęciem powierzchownych tkanek mają tendencję do samoistnych remisji po kilku latach trwania choroby i ustępują z pozostawieniem brunatnych przebarwień [5]. Ciężkie przypadki z zajęciem tkanek głębiej położonych wymagają wczesnego rozpoznania i wdrożenia odpowiedniej terapii. Warto zauważyć, że wielokrotnie prawidłowe rozpoznanie choroby jest opóźnione o kilka miesięcy lub lat [6]. Proces chorobowy zwykle dotyczy skóry, ale niekiedy może obejmować powięzie, mięśnie i kości. W wielu pracach zwraca się uwagę, że w zależności od odmiany klinicznej LoSc mogą pojawić się objawy pozaskórne [3, 6]. W świetle aktualnej wiedzy LoSc nie ulega progresji do twardziny układowej (systemic sclerosis - SSc), należy jednak pamiętać o możliwości wspólistnienia obu chorób [1, 5, 7].

W 2018 roku JDA (Japanese Dermatological Association) zaproponowało kryteria diagnostyczne LoSc, które obejmują: obecność miejscowych stwardnień skóry o dobrze ograniczonych brzegach, pogrubienie i homogenizację wiązek kolagenu w badaniu histopatologicznym oraz wykluczenie innych jednostek chorobowych o podobnym obrazie klinicznym (w tym twardziny układowej, liszaja twardzinowego, keloidów, blizn przerosłych). Rozpoznanie LoSc ustala się w przypadku spełnienia wszystkich trzech powyższych kryteriów [8].

\section{ETIOPATOGENEZA}

Etiopatogeneza LoSc nie została w pełni poznana, uważa się jednak, że duży udział mają w niej czynniki genetyczne, epigenetyczne i środowiskowe. Czynniki środowiskowe mogą odgrywać istotną rolę w patogenezie LoSc; znane są przypadki wystąpienia zmian chorobowych wskutek urazu mechanicznego, długotrwałego ucisku oraz stosowania leków [5, 9-11]. Rola krętków Borrelia burgdorferi w rozwoju LoSc jest dyskusyjna, przez wiele lat publikowano rozbieżne doniesienia $[1,5]$. Obecnie nie zaleca się rutynowego oznaczania poziomu przeciwciał przeciwko B. burgdor- 
Predisposing factors (genetic)

- $\mathrm{HLA}(\mathrm{DRB} \mid * 04: 04, \mathrm{~B} * 37)$

- Mosaicism

- Autoimmune medical history (patient/family)
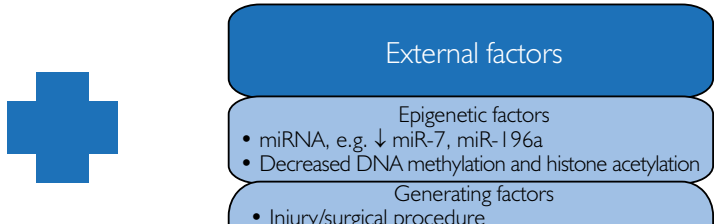

- Decreased DNA methylation and

- Injury/surgical procedure

- Injections/vaccinations

- Insect bites

- Radiation therapy

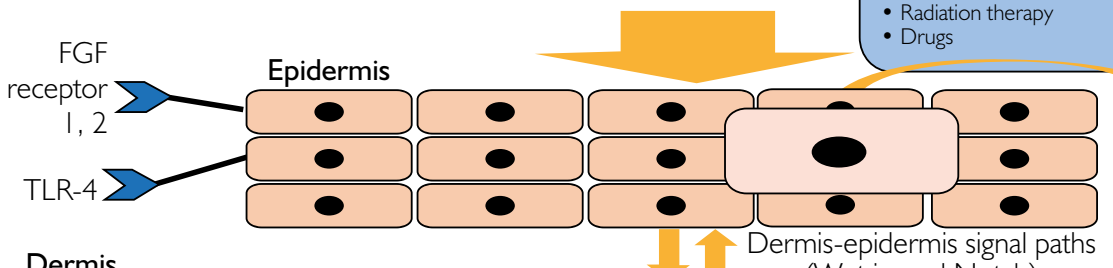

Keratinocyte

TGF- $\beta$, IL- I, IL-6, TNF- $\alpha$, PDGF,

FGF, CCL-2, SI00A9, endothelin, fibrillin- I, $\alpha$-melanotropin, FLI।

Dermis

Endothelial cell (Wnt jagged Notch)
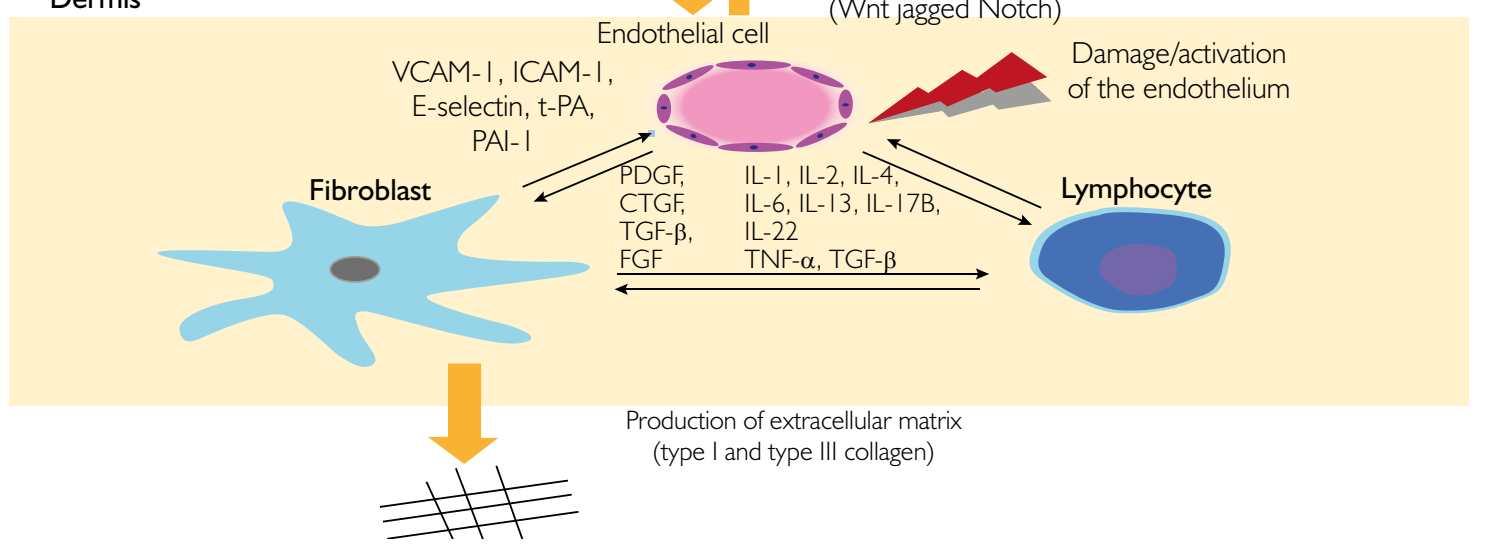

(type I and type III collagen)

Activated keratinocytes stimulate secretion of inflammatory mediators, including cytokines, which then activate immune system cells, including lymphocytes, endothelial cells, and fibroblasts. Endothelial cell activation/damage leads to an increase in expression of adhesion molecules (e.g. VCAM- I, ICAM- I), activation of T- and B-lymphocytes, and increase in the production of proinflammatory cytokines and chemokines as well as growth factors stimulating fibrosis (transforming growth factor $\beta$ - TGF- $\beta$; platelet-derived growth factor - PDGF; connective tissue growth factor - CTGF, and insulin-like growth factor - IGF).

Figure I. A diagram showing a localized scleroderma pathogenesis (original work of Katarzyna Wolska-Gawron, Ph.D.) [9]

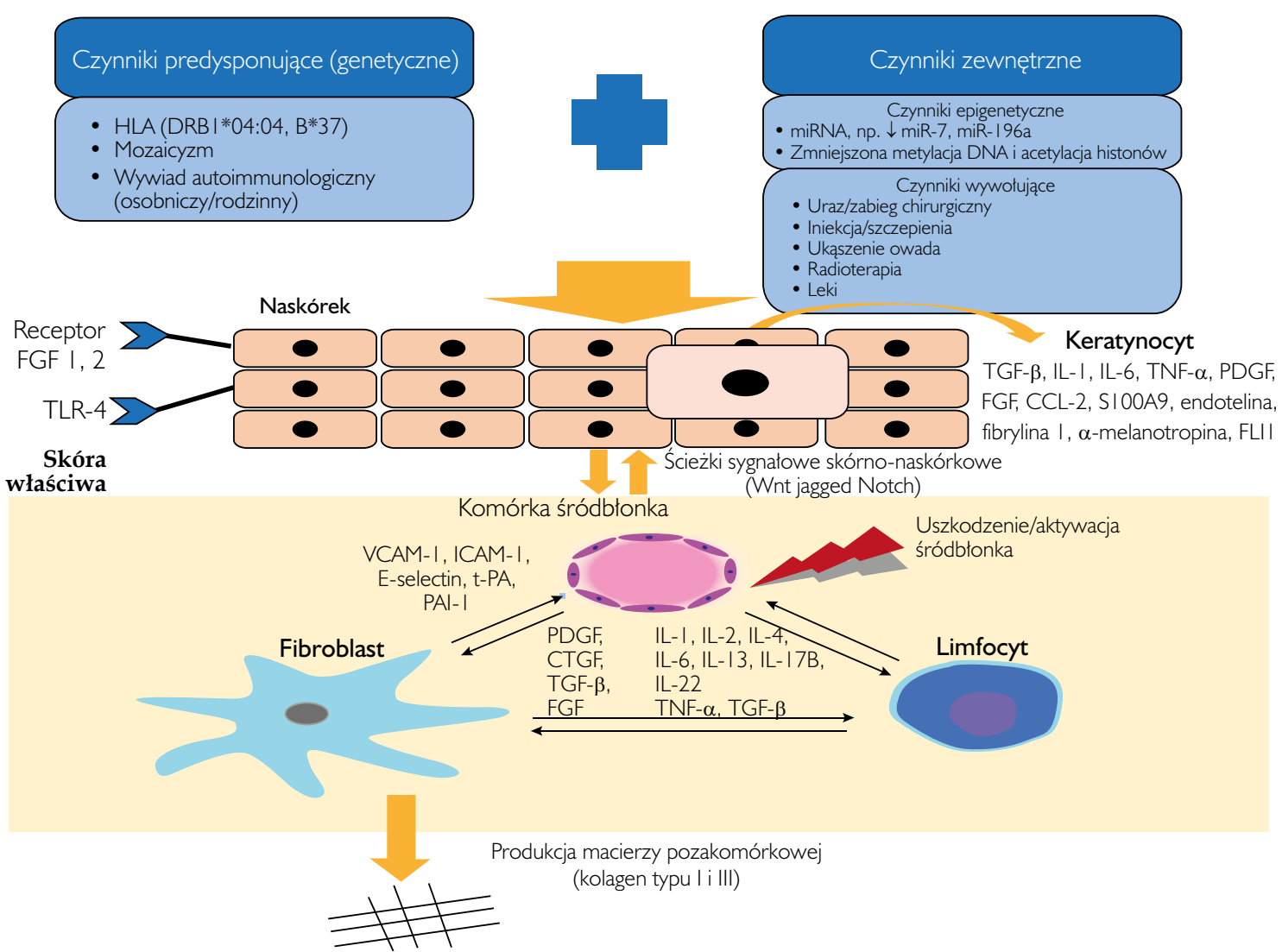

Aktywowane keratynocyty stymulują wydzielanie mediatorów zapalnych, m.in. cytokin, które w dalszej kolejności aktywują komórki układu immunologicznego, m.in. limfocyty, komórki śródbłonka oraz fibroblasty. Aktywacja lub uszkodzenie komórek śródbłonka prowadzi do zwiększenia ekspresji cząsteczek adhezyjnych (np. VCAM- I ICAM-I), aktywacji limfocytów T i B, a także wzmożonej produkcji cytokin i chemokin prozapalnych oraz czynników wzrostu stymulujących włóknienie (transformujący czynnik wzrostu $\beta$ - TGF- $\beta$; płytkopochodny czynnik wzrostu - PDGF; czynnik wzrostu tkanki tącznej - CTGF; insulinopodobny czynnik wzrostu - IGF).

Rycina I. Proponowany schemat patogenezy twardziny ograniczonej (opracowanie autorskie: dr Katarzyna Wolska-Gawron) [9] 
antibodies routinely since there is an unlikely connection between the infection with the spirochete and the LoSc development $[1,5]$. A precise mechanism of the lesion development has not been fully explained. It is thought that genetic, environmental, and yet unknown factors may activate keratinocytes to secrete inflammatory mediators, including cytokines, which then, stimulate immune system cells, including lymphocytes, endothelial cells, and fibroblasts. It appears that activation of endothelial cells and lymphocytes, which subsequently activate fibroblasts to increase collagen synthesis what leads to appearance of skin sclerotic plaques, is of key importance in the disease development (fig. 1).

\section{CLASSIFICATION OF LOCALIZED SCLERODERMA}

There have been various attempts at classifying the disease during recent years. The first one was presented by Tuffanelli and Winkelmann in 1961 that proposed three types of the disease: plaque morphea, linear scleroderma, and generalized localized scleroderma [12]. Another classification was presented in 1955 by Peterson et al. (Mayo Clinic Classification), and distinguished five classic clinical types of LoSc: plaque morphea, linear morphea, generalized morphea, bullous morphea, deep morphea [13]. The main disadvantages of both classifications were that they failed to include mixed types of LoSc that occur in about $15 \%$ of the patients [4]. A classification of juvenile localized scleroderma (JLS) proposed by Paediatric Rheumatology European Society in 2004 (Padua Consensus Classification) includes five clinical types of LoSc: localized (superficial/deep), linear (trunk, limbs, and head), generalized, deep disabling, and mixed [14]. In 2017 European Dermatology Forum proposed a classification that included five main clinical types (table 1) [1]. Eosinophilic fasciitis, which

Table I. Classification of localized scleroderma according to the guidelines of European Dermatology Forum, 2017 [I, 2]

\begin{tabular}{ll} 
LoSc type & \multicolumn{1}{c}{ Subtype } \\
& Plaque \\
\cline { 2 - 2 } & Guttate \\
\cline { 2 - 2 } Generalized & Generalized localized \\
\cline { 2 - 2 } & Disabling pansclerotic \\
\hline Linear & Linear localized \\
\cline { 2 - 2 } & En coup de sabre \\
\hline Progressive facial hemiatrophy \\
\hline Mixed & Deep \\
\hline
\end{tabular}

feri, sugerując mało prawdopodobny związek między infekcją krętkiem a rozwojem LoSc $[1,5]$. Mechanizm powstawania zmian chorobowych nie został do końca wyjaśniony. Uważa się, że czynniki genetyczne, środowiskowe i niepoznane dotychczas mogą aktywować keratynocyty do wydzielania mediatorów zapalnych, takich jak cytokiny, które następnie stymulują komórki układu immunologicznego, m.in. limfocyty, komórki śródbłonka oraz fibroblasty. Wydaje się, że duże znaczenie $\mathrm{w}$ rozwoju choroby ma aktywacja komórek śródbłonka i limfocytów, które pobudzają fibroblasty do zwiększonej syntezy kolagenu, co powoduje pojawianie się blaszek stwardnieniowych na skórze (ryc. 1).

\section{KLASYFIKACJA TWARDZINY OGRANICZONEJ}

W ostatnich kilkudziesięciu latach pojawiały się różne próby klasyfikacji choroby. Pierwszą przedstawili Tuffanelli i Winkelmann w 1961 roku, którzy zaproponowali podział na trzy odmiany choroby: twardzinę plackowatą, twardzinę linijną i twardzinę ograniczoną uogólnioną [12]. Kolejna klasyfikacja, zaprezentowana w 1995 roku przez Petersona i wsp. (Mayo Clinic Classification), wyróżniła pięć odmian klinicznych LoSc: plaque morphea, linear morphea, generalized morphea, bullous morphea, deep morphea [13]. Główną wadą obu klasyfikacji było nieuwzględnienie postaci mieszanych LoSc, które występują u ok. 15\% pacjentów [4]. Klasyfikacja postaci dziecięcej twardziny ograniczonej (juvenile localized scleroderma - JLS), zaproponowana przez Pediatric Rheumatology European Society w 2004 roku (Padua Consensus Classification), wyróżnia pięć typów klinicznych LoSc: ograniczoną (powierzchowna lub głęboka), linijną (tułowia, kończyn i głowy), uogólnioną, zniekształcającą głęboką i mieszaną [14]. European Dermatology Forum w 2017 roku zaproponowało klasyfikację choroby uwzględniającą pięć głównych typów klinicznych (tab. 1) [1]. Eozynofilowe zapalenie powięzi, klasyfikowane wcześniej jako podtyp twardzi-

Tabela I. Klasyfikacja twardziny ograniczonej wg wytycznych European Dermatology Forum z 2017 roku [I, 2]

\begin{tabular}{ll} 
Typ LoSc & \multicolumn{1}{c}{ Podtyp } \\
Ograniczona & Plackowata \\
\cline { 2 - 2 } & Grudkowa \\
\cline { 2 - 2 } & Ograniczona pierwotnie zanikowa (powierzchowna) \\
\hline Uogólniona & Ograniczona uogólniona \\
\cline { 2 - 2 } & Zniekształcająca głęboka \\
\hline Linijna & Linijna kończyn \\
\cline { 2 - 2 } & Typu cięcia szablą \\
\cline { 2 - 2 } & Postępujący zanik połowiczy twarzy \\
\hline Głęboka & Głęboka \\
\hline Mieszana & Linijna + plackowata \\
& Linijna + uogólniona $\}$ \\
\hline
\end{tabular}


has earlier been classified as a sub-type of generalized localized/deep scleroderma, is currently considered to be a separate disease entity $[1,5]$.

\section{LOCALIZED SCLERODERMA - CLINICAL CHARACTERISTICS}

An active period of LoSc includes inflammation in the form of red and violet spots and/or wax-yellow or porcelain-white sclerotic plaques with a lilac ring, which may be accompanied by subjective symptoms such as pain and/or pruritus [3]. In some cases, hyperpigmentation spots without the presence of hardenings are dominating clinical symptoms from the beginning of the disease. During a non-active period, there are present sclerotic plaques and/or atrophy of the skin/subcutis and dark red hyperpigmentations or discolourations. In some patients morphea-like lesions may self-limit themselves within 3-5 years, however, in many cases the disease has a chronic and recurrent course [5].

\section{Plaque morphea}

Plaque morphea is the most common type of LoSc in adults [1]. It manifests itself with the presence of oval/round plaques with the diameter bigger than $1 \mathrm{~cm}$ that are most often found on the torso (inframammary region, hypogastrium, groins) and extremities $[1,2,5]$. Initially, the exanthemata are erythematous and/or there are wax-yellow or porcelain-white sclerotic plaques with a lilac ring. With time, the sclerosis subsides leaving hyper-/hypopigmentation atrophic foci without skin adnexa, but sometimes with telangiectasias $[1,2,5]$.

\section{Guttate morphea}

Guttate morphea is characterized by the presence of multiple small (smaller than $1 \mathrm{~cm}$ ) white and yellow papulae with a slightly increased tenacity that resemble lichen sclerosus (LS) and most often affect the trunk $[1,2]$. Guttate morphea is a type of LoSc that is difficult to be clinically differentiated from the LoSc since it requires a histopathological examination, in which a distinguishing feature is the presence of elastic fibres in a sample taken from an exanthema with the guttate morphea morphology. In some cases, both disease entities may co-exist.

\section{Atrophoderma of Pasini and Pierini}

Atrophoderma of Pasini and Pierini (APP) is a mild form of LoSc, in which there are no scleroses, it is found superficially and is a bit more common in children [2]. It is characterized by the presence of sharply demarcated grey and dark brown patches ny ograniczonej uogólnionej lub głębokiej, jest obecnie uważane za odrębną jednostkę chorobową $[1,5]$.

\section{TWARDZINA OGRANICZONA - CHARAKTERYSTYKA KLINICZNA}

W okresie aktywnym LoSc pojawiają się zmiany zapalne $\mathrm{w}$ postaci rumieniowo-fioletowych plam $\mathrm{i} / \mathrm{lub}$ woskowożółte lub porcelanowobiałe blaszki stwardnieniowe, otoczone rumieniową obwódką (lilac ring), którym mogą towarzyszyć objawy subiektywne w postaci bolesności i/lub świądu [3]. W niektórych przypadkach od początku choroby głównym objawem klinicznym są plamy hiperpigmentacyjne, bez obecności stwardnień. W okresie nieaktywnym obecne są blaszki stwardnieniowe i/lub zanik skóry lub tkanki podskórnej oraz brunatne przebarwienia lub odbarwienia. U niektórych chorych zmiany w postaci morphea mogą ulegać samoograniczaniu w czasie 3-5 lat, jednak u wielu choroba ma przewlekły, nawrotowy przebieg [5].

\section{Twardzina plackowata}

Twardzina plackowata (plaque morphea) jest najczęstszą postacią LoSc u osób dorosłych [1]. Objawia się obecnością owalnych lub okrągłych blaszek o średnicy większej niż $1 \mathrm{~cm}$, które najczęściej zajmują okolicę tułowia (okolica podsutkowa, podbrzusze, pachwiny) i konczyn $[1,2,5]$. W początkowym etapie choroby wykwity mają barwę rumieniową i/lub obecne są woskowożółte lub porcelanowobiałe stwardniałe blaszki, które otacza fioletowa, sinoczerwona obwódka (lilac ring). Następnie stwardnienie ustępuje z pozostawieniem hiper- lub hipopigmentacyjnych ognisk atroficznych pozbawionych przydatków skóry, niekiedy z obecnością teleangiektazji $[1,2,5]$.

\section{Twardzina grudkowa lub kropelkowa}

Twardzina grudkowa (guttate morphea) charakteryzuje się obecnością mnogich, drobnych (mniejszych niż $1 \mathrm{~cm}$ ), biało-żółtych grudek o nieznacznie wzmożonej spoistości, które przypominają liszaj twardzinowy (lichen sclerosus - LS) i najczęściej zajmują skórę tułowia [1, 2]. Różnicowanie kliniczne tej odmiany LoSc z LS jest bardzo trudne, wymagane jest wykonanie badania histopatologicznego, w którym cechą różnicującą jest obecność włókien sprężystych w materiale pobranym z wykwitu o morfologii twardziny grudkowej. W części przypadków możliwe jest także współistnienie obu jednostek chorobowych.

\section{Twardzina ograniczona pierwotnie zanikowa}

Twardzina ograniczona pierwotnie zanikowa (atrophoderma Pasini Pierini - APP) jest łagodną postacią LoSc zlokalizowaną powierzchownie, w której nie występują 
that are flat or are marked by a slight depression of the skin; there are no accompanying scleroses [1, 2, 15]. The lesions are symmetric and affect the skin of the trunk and proximal sections of the extremities $[1,4]$. The lesions should be differentiated from fixed erythema, and they do not require treatment. In about $20 \%$ of patients, co-existence of APP and plaque morphea is confirmed [2].

\section{GENERALIZED LOCALIZED SCLERODERMA}

Generalized localized scleroderma affects 7-9\% of patients and belongs to LoSc forms that have a severe course [1, 2]. Generalized localized scleroderma is diagnosed when there are present four or more sclerotic foci with the diameter greater than $3 \mathrm{~cm}$, which are found in at least two anatomical regions [1, 2]. Typical lesions are symmetric on the skin of the trunk, arms and extremities, save for the face, hands and feet; they are characterized by fast progress. They should be differentiated from systemic sclerosis (no Raynaud's phenomenon, capillaroscopic lesions and involvement of internal organs) $[1-3,5,16]$. In about $1 / 3$ of cases, there might be a concomitant LS on the genital organs. Some patients may report subjective symptoms such as pain, pruritus, fatigue, muscle and joint pain, whereas laboratory tests may reveal the presence of a rheumatoid factor (RF), eosinophilia, and non-characteristic antinuclear antibodies being an expression of autoimmune reaction [3].

\section{Disabling pansclerotic scleroderma}

Disabling pansclerotic scleroderma is the most severe clinical form of LoSc with aggressive and progressive course. It affects $1-2 \%$ of patients, mainly children below $14 \mathrm{y} / \mathrm{o}$. The disease affects not only the skin, but also the subcutis, muscles, joints, and bones; it develops very dynamically and may lead to disability within a short period of time. Progressing, extent and deep scleroses appear typically bilaterally on the distal parts of extremities, and gradually affect also the torso, head and neck, but they spare the hands and feet. The disease involves contractures and limitations to joint mobility that are accompanied with non-healing ulcerations and calcinosis $[8,16]$. Due to the impairment of wound-healing processes and common presence of ulcerations, the patients suffering from disabling pansclerotic scleroderma are burdened with an increased risk for development of squamous cell carcinoma (SCC) [8]. Literature includes severe cases of disabling pansclerotic scleroderma complicated with spontaneous amputation of ears, osteolysis of distal phalanges, marasmus, haematosepsis, and parenchymal lung disease [17]. Disabling pansclerotic scleroderma is often accompanied by deviations in laboratory tests (anaemia, thrombo- stwardnienia. Nieco częściej występuje ona u dzieci niż u dorosłych [2]. Charakteryzuje się obecnością dobrze odgraniczonych plam barwy szarobrunatnej o płaskiej lub nieznacznie zagłębionej powierzchni, bez towarzyszącego stwardnienia $[1,2,15]$. Zmiany przybierają układ symetryczny i zajmują skórę tułowia oraz proksymalnych odcinków kończyn [1,4]. Należy je różnicować z rumieniem trwałym, nie wymagają one leczenia. U około $20 \%$ pacjentów stwierdza się współwystępowanie APP i twardziny plackowatej [2].

\section{TWARDZINA OGRANICZONA UOGÓLNIONA}

Twardzina ograniczona uogólniona (generalized localized scleroderma) występuje u 7-9\% pacjentów i należy do postaci LoSc o ciężkim przebiegu [1, 2]. Twardzinę rozpoznaje się w przypadku obecności czterech lub więcej ognisk stwardnienia o średnicy większej niż $3 \mathrm{~cm}$, które lokalizują się w co najmniej dwóch okolicach anatomicznych [1, 2]. Zwykle zmiany chorobowe obecne są symetrycznie na skórze tułowia, ramion i kończyn, oszczędzają twarz, ręce, stopy i cechują się szybką progresją. Wymagają różnicowania z twardziną układową (brak objawu Raynauda, zmian kapilaroskopowych i zajęcia narządów wewnętrznych) $[1-3,5,16]$. W około $1 / 3$ przypadków mogą współwystępować zmiany na narządach płciowych. Część pacjentów może zgłaszać objawy subiektywne, takie jak bolesność, świąd, zmęczenie, bóle mięśniowe i stawowe, a w badaniach laboratoryjnych może być obecny czynnik reumatoidalny (RF), eozynofilia i niecharakterystyczne przeciwciała przeciwjądrowe jako wyraz odczynu autoimmunologicznego [3].

\section{Twardzina uogólniona zniekształcająca}

Twardzina uogólniona zniekształcająca (disabling pansclerotic scleroderma) jest najcięższą postacią kliniczną LoSc o agresywnym i postępującym przebiegu. Występuje u 1-2\% chorych, głównie u dzieci poniżej 14. roku życia. Choroba zajmuje nie tylko skórę, lecz także tkankę podskórną, mięśnie, stawy, kości, rozwija się bardzo dynamicznie i w krótkim czasie może prowadzić do inwalidztwa. Zwykle pojawiają się szybko postępujące, rozległe i głębokie stwardnienia obustronnie na dystalnych częściach kończyn, które stopniowo zajmują także tułów, głowę i szyję, ale oszczędzają ręce i stopy. W przebiegu choroby dochodzi do powstania przykurczów i ograniczenia ruchomości stawów, którym towarzyszy obecność niegojących się owrzodzeń i wapnicy $[8,16]$. Ze względu na upośledzenie procesu gojenia ran i częste występowanie owrzodzeń chorzy z twardziną uogólnioną zniekształcającą są obarczeni zwiększonym ryzykiem rozwoju raka kolczystokomórkowego (squamous cell carcinoma - SCC) [8]. W piśmiennictwie są doniesienia o ciężkich przypadkach disabling pansclerotic scleroderma 
cytopenia, eosinophilia, hyper/hypoglobulinemia), which correlate with the disease activity [17].

\section{LINEAR SCLERODERMA}

\section{Linear localized scleroderma}

Linear localized scleroderma is the most popular clinical type of LoSc in paediatric patients (51-65\%), and the peak of morbidity occurs at the age of 7-8, although it may also affect the adults $[5,14,16]$. The disease manifests itself with the presence of linear sclerotic foci that run along the Blaschko's lines, most often unilaterally and mainly on the extremities. It is usually severe and burdened with high risk of contractures and limitations to joint mobility, as well as growth disorders, atrophy of extremities and scoliosis that sometimes may require surgical or orthopaedic interventions [16, 18]. As the sclerosis disappear, atrophies appear that mat affect not only the skin, but also the subcutis and muscles; they may be quite deep. The disease may sometimes be accompanied by arthritis, and RF may be present in the serum. Recently, Merlin et al. have described a so-called dry synovitis, which is the cause of articular lesions without inflammation in a paediatric population of patients affected by localized scleroderma. Fibrosis of the joint capsule and fasciae may be a result of dry synovitis, and is characterized by painful limitation to the mobility of affected joints. Such cases require magnetic resonance imaging (MRI) of the involved areas in order to make a diagnosis [19].

\section{En coup de sabre}

En coup de sabre (ECDS) manifests itself by the presence of linear atrophy and/or hardening of the skin, subcutis, muscles, and bones; it usually starts at the level of the upper eyebrow ridge and reaches the scalp, where a cicatricial alopecia focus appears [20, 21]. There are known descriptions of patients with ECDS, in whom eruptions spread below the eyebrows involving the eyelids, eyelashes or the skin on the nose [22]. The lesion is usually singular, however, double lines may sometimes occur [23, 24]. The disease may involve the sight organ (deformation of eyelids, uveitis, episcleritis) and central nervous system (CNS) (convulsions, migraine, trigeminal neuralgia, vascular malformations) [24, 25]. The CNS disorders are sometimes unilateral, and their progress does not always correlate with ECDS intensity, hence, head MRI is recommended in every patient with ECDS, regardless of the incidence of the above symptoms [24]. Furthermore, there are described cases in which neurological disorders preceded the appearance of skin lesions [26]. ECDS may be concomitant with powikłanych samoistną amputacją uszu, osteolizą paliczków dystalnych palców, kacheksją, posocznicą i chorobą śródmiąższową płuc [17]. Twardzinie uogólnionej zniekształcającej często towarzyszą odchylenia w badaniach laboratoryjnych (anemia, trombocytopenia, eozynofilia, hiperglobulinemia), które korelują z aktywnością choroby [17].

\section{TWARDZINA LINIJNA}

\section{Twardzina linijna kończyn}

Twardzina linijna kończyn (linear localized scleroderma) jest najczęstszą odmianą kliniczną LoSc u pacjentów pediatrycznych (51-65\%), a szczyt zachorowań przypada na 7.-8. rok życia, mimo że choroba może występować także u osób dorosłych $[5,14,16]$. Objawia się obecnością linijnych, pasmowatych ognisk stwardnień, które biegną wzdłuż linii Blaschko, najczęściej jednostronnie, głównie w obrębie kończyn. Schorzenie ma zwykle ciężki przebieg i obarczone jest dużym ryzykiem powstania przykurczów i ograniczenia ruchomości stawów, a także zaburzeń wzrostu i atrofii kończyn oraz skoliozy, które mogą wymagać interwencji chirurgicznej lub ortopedycznej [16, 18]. Wraz z ustępowaniem stwardnień pojawiają się zaniki, które obejmują nie tylko skórę, lecz także tkankę podskórną oraz mięśnie i mogą być dość głębokie. Chorobie czasami towarzyszy zapalenie stawów, a w surowicy może być obecny czynnik RF. Ostatnio Merlin i wsp. opisali tzw. suche zapalenie błony maziowej będące przyczyną zmian stawowych bez obecności cech zapalnych w populacji dzieci chorych na twardzinę ograniczoną. Włóknienie torebki stawowej, ścięgien i powięzi może być wynikiem suchego zapalenia błony maziowej i cechuje się obecnością bezbolesnego ograniczenia ruchomości zajętych stawów. W takich przypadkach wymagane jest wykonanie badania rezonansu magnetycznego (magnetic resonance imaging - MRI) zajętych okolic w celu ustalenia rozpoznania [19].

\section{Twardzina typu cięcia szablą}

Twardzina typu cięcia szablą (en coup de sabre - ECDS) objawia się obecnością linijnego zaniku i/lub stwardnienia skóry, tkanki podskórnej, mięśni, kości i przebiega zwykle od poziomu górnej krawędzi brwi do owłosionej skóry głowy, gdzie pojawia się ognisko łysienia bliznowaciejącego [20, 21]. Znane są opisy pacjentów z ECDS, u których stwierdzono szerzenie się wykwitów poniżej linii brwi, z zajęciem powiek, rzęs lub skóry nosa [22]. Zmiana jest najczęściej pojedyncza, ale czasami mogą występować linie podwójne [23, 24]. Choroba może przebiegać z zajęciem narządu wzroku (zniekształcenie powiek, zapalenie błony naczyniowej, zapalenie nadtwardówki) i ośrodkowego układu nerwowego (OUN; drgawki, migrena, neuralgia nerwu trójdzielnego, malformacje naczyniowe) [24, 25]. Zaburzenia w OUN wy- 
progressive facial hemiatrophy (PFH) in $20-40 \%$ of patients [24].

\section{Progressive facial hemiatrophy}

Progressive facial hemiatrophy (Parry-Romberg syndrome - PFH) is a clinical type of LoSc that involves the skin, subcutis, muscles, and bones on one side of the face. The disease may occur at every age, however, it most often affects children below $10 \mathrm{y} / \mathrm{o}$, in whom it leads to atrophy of soft and osseous tissues, oral structures and teeth (deformation of the face and mandible, unilateral tongue atrophy, masseter muscle fatigue, soft and hard palate atrophy, mandible hypoplasia, atrophy of alveolar processes, malocclusion, delayed teeth eruption, teeth loss) [4, 27]. In $20 \%$ of cases PFH may be accompanied by neurological symptoms (including headaches, migraines, convulsions, trigeminal nerve paralysis, paresthesia, hemiplegia, anomalies of intracranial vessels), and in $15 \%$ of case by ocular symptoms (including enophthalmos, strabismus, eyelid atrophy, uveitis, glaucoma, diplopia, Horner's syndrome, mydriasis) [27-30]. Guerrerosantos et al. proposed a 4-grade classification of PFH based on the level of tissue atrophy: type 1 - minimal soft tissue atrophy in a severe phase of the disease, usually between the age of 10-20; type 2 - moderate soft tissue atrophy with no influence on osseous and cartilaginous tissues; type 3 - moderately severe soft tissue atrophy with atrophy of the osseous and cartilaginous tissues, typical for patients who developed the disease before the age of 10; type 4 - severe soft tissue atrophy with atrophy of the osseous and cartilaginous tissues, and disorders of affected organs (nose, oral cavity, eye) [31]. PFH may be concomitant with hyperthyroidism, hypertrophic cardiomyopathy (HCM), rheumatoid arthritis, or systemic lupus erythematosus (SLE) [26].

\section{DEEP SCLERODERMA}

Deep scleroderma is a rare type of LoSc that may affect both children and adults. It is characterized by the presence of scleroses found within the deep layers of the skin, subcutis, fasciae and muscles; symmetrically most often on the extremities, whereas the skin is not involved and there is no lilac ring $[1,3]$.

\section{MIXED SCLERODERMA}

Mixed scleroderma is a combination of at least two clinical types of LoSc; most often it is linear scleroderma and plaque morphea or linear scleroderma and generalized localized scleroderma [1, 2]. It affects about $15 \%$ of patients, mainly children $[1,2]$. stępują niekiedy obustronnie, a ich progresja nie zawsze koreluje z nasileniem ECDS, dlatego rekomenduje się wykonanie MRI głowy u każdego pacjenta z ECDS, niezależnie od występowania wymienionych objawów [24]. Opisywano również przypadki, w których zaburzenia neurologiczne poprzedzały pojawienie się zmian skórnych [26]. ECDS może współwystępować u 20-40\% pacjentów z postępującym zanikiem połowiczym twarzy (progressive facial hemiatrophy - $\mathrm{PFH}$ ) u $20-40 \%$ pacjentów [24].

\section{Postępujący zanik połowiczy twarzy}

Postępujący zanik połowiczy twarzy (Parry-Romberg syndrome, progressive facial hemiatrophy - PFH) jest odmianą kliniczną LoSc, która przebiega z zajęciem skóry, tkanki podskórnej, mięśni i kości połowy twarzy. Choroba może wystąpić w każdym wieku, jednak najczęściej dotyczy dzieci poniżej 10. roku życia, u których prowadzi do zaniku tkanek miękkich i kostnych, struktur jamy ustnej oraz zębów (deformacje twarzy oraz szczęki, jednostronna atrofia języka, męczliwość mięśnia żwacza, atrofia podniebienia miękkiego i twardego, hipoplazja szczęki, atrofia wyrostków zębodołowych, wady zgryzu, opóźnione wyrzynanie się zębów, wypadanie zębów) $[4,27]$. Postępującemu zanikowi połowiczemu twarzy w $20 \%$ przypadków mogą towarzyszyć objawy neurologiczne (m.in. bóle głowy, migrena, drgawki, porażenie nerwu trójdzielnego, parestezje, hemiplegia, anomalie naczyń śródczaszkowych) oraz w 15\% przypadków objawy okulistyczne (m.in. enoftalmia, zez, atrofia powiek, zapalenie błony naczyniowej oka, jaskra, diplopia, zespół Hornera, mydriaza) [27-30]. Guerrerosantos i wsp. zaproponowali 4-stopniową klasyfikację postępującego zaniku połowiczego twarzy PFH, na podstawie stopnia atrofii tkanek: typ 1 - minimalna atrofia tkanek miękkich w ostrej fazie choroby, przeważnie między 10. a 20. rokiem życia; typ 2 - umiarkowana atrofia tkanek miękkich, bez wpływu na tkankę kostną i chrzęstną; typ 3 - średnio nasilona atrofia tkanek miękkich $\mathrm{z}$ atrofią tkanki kostnej i chrzęstnej, charakterystyczna dla pacjentów, u których choroba rozpoczęła się przed 10. rokiem życia; typ 4 - nasilona atrofia tkanek miękkich z atrofią tkanki kostnej i chrzęstnej, zaburzenia funkcji zajętych narządów (nos, jama ustna, oko) [31]. PFH może współwystępować z nadczynnością tarczycy, kardiomiopatią przerostową, reumatoidalnym zapaleniem stawów, toczniem rumieniowatym układowym [26].

\section{TWARDZINA GŁEBBOKA}

Twardzina głęboka (deep scleroderma) jest rzadką odmianą LoSc, która może dotyczyć dzieci i osób dorosłych. Charakteryzuje się obecnością stwardnień 


\section{CLINICAL ASSESSMENT OF A PATIENT WITH LOCALIZED SCLERODERMA}

All patients with LoSc should have a medical history taken in order to determine the beginning of lesions, conduct physical examination (with assessment of genital organs for LS-type lesions), and assess activity/intensity of the disease and tissue damage, as well as possible progression of lesions. To assess the activity/intensity and tissue damage a special form is used, i.e. the localized scleroderma assessment tool (LoSCAT) [3]. Moreover, it is worth to take clinical images, what surely facilitates assessment of efficacy of the applied treatment and the disease course during further observations. Sometimes the disease diagnosis is delayed what affects the efficacy of the used therapy. Localized scleroderma is defined as active if during the previous month a new erythematous lesion and/or sclerotic plaque has appeared or existing inflammatory lesions (erythema and/or lilac ring) and/or sclerotic plaque have become larger. During non-active period, plaque morphology changes - erythema disappears, hyperpigmentation appears, skin hardening subsides, and atrophic features of the skin (shiny surface, translucent blood vessels) and/or the subcutis (blurred ridges of the eruptions, "paving stones" appearance) are present [3]. In some cases, non-active lesions may be accompanied by telangiectasias, which require differentiation from an erythema typical for an active disease phase (dermoscopic assessment is recommended) [3].

Localized scleroderma does not involve internal organs and does not require patients to be diagnosed for organ lesions. Nevertheless, there exist some LoSc types, in which clinical form of the disease conditions the necessity for additional examinations. Patients with LoSc within the skin of the head require ophthalmological assessment for involvement of the sight organ [3]. In case of accompanying neurological symptoms, it is recommended to refer the patient for a neurological consultation, whereas jaw/mandible involvement makes it necessary for the patient to be assessed by a dentist or an oral and maxillofacial surgeon [3]. In case of ECDS-type lesions, even when there are no neurological symptoms, head MRI is recommended. Distribution of sclerotic lesions on the trunk or extremities, with concomitant muscle symptoms, requires additional examinations, including soft tissue MRI/ultrasound and laboratory tests (aldolase, creatinine kinase, LDH, ESR) $[1,3]$. A patient with LoSc including joint involvement (joint pain, joint oedema, positive RF) should be consulted by a rheumatologist, whereas the presence of osteoarticular system dysfunctions w obrębie głębokich warstw skóry, tkanki podskórnej, powięzi i mięśni, najczęściej na kończynach, symetrycznie, przy czym skóra nie jest zajęta i nie występuje lilac ring [1,3].

\section{TWARDZINA MIESZANA}

Twardzina mieszana (mixed scleroderma) stanowi kombinację co najmniej dwóch postaci klinicznych LoSc, najczęściej twardziny linijnej i plackowatej lub twardziny linijnej i ograniczonej uogólnionej [1, 2]. Występuje u około $15 \%$ pacjentów, głównie u dzieci $[1,2]$.

\section{OCENA KLINICZNA PACJENTA Z TWARDZINA OGRANICZONA}

U każdego chorego z LoSc należy zebrać dokładny wywiad, aby ustalić początek zmian, przeprowadzić dokładne badanie fizykalne (z oceną narządów płciowych pod kątem obecności zmian w postaci LS) oraz ocenić aktywność lub nasilenie choroby i uszkodzenie tkanek, a także ewentualną progresję zmian. Do tego celu wykorzystywany jest specjalny formularz oceny aktywności/ nasilenia i uszkodzenia tkanek (LoSCAT) [3]. Warto także wykonać zdjęcia kliniczne, które niewątpliwie w dalszej obserwacji ułatwią ocenę skuteczności zastosowanego leczenia lub progresji choroby. Czasami rozpoznanie choroby jest znacznie opóźnione, co wpływa na skuteczność stosowanej terapii. Twardzinę ograniczoną definiuje się jako aktywną, jeśli w ostatnim miesiącu pojawiła się nowa zmiana rumieniowa i/lub blaszka stwardnieniowa albo istniejące zmiany zapalne (rumień i/lub sinofiołkowa obwódka) i/lub blaszka stwardnieniowa się powiększyły. W okresie nieaktywnym morfologia blaszki się zmienia - zanika rumień, pojawia się hiperpigmentacja, ustępuje stwardnienie i obecne są cechy atrofii skóry (błyszcząca powierzchnia, prześwitujące naczynia krwionośne) i/lub tkanki podskórnej (zatarcie granic wykwitu, wygląd kostki brukowej) [3]. W niektórych przypadkach zmianom nieaktywnym mogą towarzyszyć teleangiektazje, które wymagają różnicowania z rumieniem typowym dla fazy aktywnej choroby (rekomendowana ocena dermoskopowa) [3].

Twardzina ograniczona nie zajmuje narządów wewnętrznych, dlatego nie jest wymagane diagnozowanie pacjenta pod kątem zmian narządowych. Istnieją jednak pewne odmiany LoSc, w których postać kliniczna choroby warunkuje konieczność wykonania badań dodatkowych. Pacjenci z LoSc umiejscowioną w obrębie skóry głowy wymagają oceny okulistycznej pod kątem zajęcia narządu wzroku [3]. W przypadku towarzyszących objawów neurologicznych wskazane jest skierowanie chorego na konsultację neurologiczną, natomiast w przypadku zajęcia szczęki lub żuchwy niezbędna jest ocena pacjenta przez stomatologa lub 
Table 2. Extracutaneous manifestation in localized scleroderma $[3,57,58]$

\begin{tabular}{|c|c|}
\hline Lesion type & Symptoms \\
\hline Muscle and articular (I 5-68\%) & Joint pain, muscle atrophy, asymmetry of both extremities, joint contractures \\
\hline Neurological (4.4-31\%) & Headaches/migraines, convulsions \\
\hline Ocular (3\%) & Uveitis, episcleritis, enophthalmos \\
\hline $\begin{array}{l}\text { Abnormalities in the mandible } \\
\text { and teeth }\end{array}$ & $\begin{array}{l}\text { Mandible deformation, atrophy of the mandible and alveolar processes, delayed teeth } \\
\text { eruptions, teeth loss }\end{array}$ \\
\hline $\begin{array}{l}\text { Pulmonary* ( } 12 \% \text { of adults } \\
\text { vs. } 7 \% \text { of children) }\end{array}$ & $\begin{array}{l}\text { More often in adults (I } 2 \%) \text { than children (7\%) } \\
\text { Mild to moderate restrictive lung function (function test) } \\
\text { Parenchymal lung disease (unilaterally - on the side of skin lesions) } \\
\text { Lung involvement is more common in patients with generalized localized scleroderma } \\
\text { Patients with ANA are burdened with a higher risk of lung involvement }\end{array}$ \\
\hline $\begin{array}{l}\text { Vasomotor* ( } 7 \% \text { of adults vs. } 2 \% \\
\text { of children) }\end{array}$ & Raynaud's phenomenon \\
\hline Gastrological* ( $1-5 \%)$ & Gastroesophageal reflux, dysphagia \\
\hline Cardiac* (I-5\%) & Arrhythmia, pericarditis \\
\hline Nephrological* (I-5\%) & Proteinuria, nephritis \\
\hline
\end{tabular}

*Disorders as common as in the general population.

Tabela 2. Objawy pozaskórne w przebiegu twardziny ograniczonej $[3,57,58]$

\begin{tabular}{|c|c|}
\hline Rodzaj zmian & Objawy \\
\hline Mięśniowo-stawowe ( $15-68 \%)$ & Bóle stawów, zanik mięśni, asymetria obwodu kończyn, przykurcze w stawach \\
\hline Neurologiczne $(4,4-3 \mid \%)$ & Bóle głowy lub migrena, drgawki \\
\hline Oczne (3\%) & Zapalenie naczyniówki, zapalenie nadtwardówki, enoftalmia \\
\hline $\begin{array}{l}\text { Nieprawidłowości szczęki } \\
\text { i zębów }\end{array}$ & $\begin{array}{l}\text { Deformacje szczęki, atrofia szczęki i wyrostków zębodołowych, opóźnione wyrzynanie się } \\
\text { zębów, wypadanie zębów }\end{array}$ \\
\hline $\begin{array}{l}\text { Płucne* (I } 2 \% \text { dorośli } \\
\text { vs } 7 \% \text { dzieci) }\end{array}$ & $\begin{array}{l}\text { Częściej u dorosłych ( I 2\%) niż u dzieci (7\%) } \\
\text { Łagodne do umiarkowanych zaburzenia restrykcyjne (testy czynnościowe) } \\
\text { Choroba śródmiąższowa płuc (jednostronne - po stronie zmian skórnych) } \\
\text { Zajęcie płuc częstsze wśród pacjentów z twardziną ograniczoną uogólnioną } \\
\text { Pacjenci z dodatnimi przeciwciałami ANA są obciążeni wyższym ryzykiem zajęcia płuc }\end{array}$ \\
\hline $\begin{array}{l}\text { Naczynioruchowe* (7\% dorośli } \\
\text { vs } 2 \% \text { dzieci) }\end{array}$ & Objaw Raynauda \\
\hline Gastrologiczne* $(1-5 \%)$ & Refluks żołądkowo-przełykowy, dysfagia \\
\hline Kardiologiczne* $(\mid-5 \%)$ & Arytmia, zapalnie osierdzia \\
\hline Nefrologiczne* $(1-5 \%)$ & Białkomocz, zapalanie nerek \\
\hline
\end{tabular}

*Zaburzenia spotykane z częstościq porównywalnq z populacją ogólnq̨.

(asymmetry of extremities, contractures) is an indication for orthopaedic consultation and usage of proper physical therapy procedures [3]. Some severe forms of LoSc may include various extracutaneous manifestations, which are presented in table 2 .

\section{DIFFERENTIAL DIAGNOSIS AND DIAGNOSTIC PROCEDURES}

Localized scleroderma requires to be differentiated from diseases that are similar in clinical picture. Table 3 presents differential diagnosis with regard to the form of LoSc and the disease phase $[1-3,5]$. chirurga szczękowo-twarzowego [3]. Jeśli obecne są zmiany w postaci ECDS, nawet przy braku objawów neurologicznych, wskazane jest wykonanie MRI głowy. Umiejscowienie zmian twardzinowych na tułowiu lub kończynach przy współistnieniu objawów mięśniowych powoduje, że konieczne jest wykonanie badań dodatkowych, w tym MRI lub ultrasonografii (USG) tkanek miękkich oraz badań laboratoryjnych (aldolaza, kinaza kreatyninowa, LDH, OB) [1, 3]. Pacjenta z LoSc, której towarzyszą cechy zajęcia stawów (ból stawów, obrzęk stawów, dodatni czynnik reumatoidalny), można skonsultować z reumatologiem, natomiast obecność zaburzeń funkcjonowania układu kostno-stawowego (asymetria kończyn, przykurcze) może być wskaza- 
Table 3. Differential diagnosis of specific localized scleroderma clinical types $[1-3,5]$

\begin{tabular}{|c|c|}
\hline LoSc type & Differential diagnostics \\
\hline Localized (inflammatory lesions) & $\begin{array}{l}\text { Lichen sclerosus, granulosarcoma, granuloma annulare, fixed erythema, chronic erythema } \\
\text { migrans, porokeratosis of Mibelli, cutaneous radiation syndrome, urticaria pigmentosa }\end{array}$ \\
\hline Localized (sclerosis) & Necrobiosis lipoidica, circumscribed myxoedema, morpheaform basal cell carcinoma \\
\hline Localized (hyperpigmentation lesions) & $\begin{array}{l}\text { Post-inflammatory hyperpigmentation, café au lait spots, lichen planus induced by solar } \\
\text { radiation, erythema dyschromicum perstans }\end{array}$ \\
\hline Localized (atrophic lesions) & Lichen sclerosus, scarring, atrophic dermatitis of the extremities, cellulitis \\
\hline Generalized & $\begin{array}{l}\text { Systemic sclerosis, mixed connective tissue disease, GVHD, porphyria cutanea tarda, } \\
\text { scleredema adultorum of Buschke, scleromyxedema, nephrogenic systemic fibrosis }\end{array}$ \\
\hline Linear & Progressive lipodystrophy, glucocorticosteroids-induced lipoatrophy, site-specific lipoatrophy \\
\hline Deep & Inflammation of the subcutis, lupus panniculitis \\
\hline
\end{tabular}

Tabela 3. Diagnostyka różnicowa poszczególnych postaci klinicznych twardziny ograniczonej [ I-3, 5]

\begin{tabular}{ll}
$\begin{array}{l}\text { Typ LoSc } \\
\text { Ograniczona (zmiany zapalne) }\end{array}$ & $\begin{array}{l}\text { Liszaj twardzinowy, ziarniniak grzybiasty, ziarniniak obrączkowaty, rumień trwały, } \\
\text { rumień przewlekły pełzający, porokeratoza Mibellego, skórny zespół popromienny, } \\
\text { mastocytoza skórna }\end{array}$ \\
\hline Ograniczona (stwardnienie) & $\begin{array}{l}\text { Obumieranie tłuszczowate, obrzęk śluzowaty podudzi, rak podstawnokomórkowy } \\
\text { twardzinopodobny }\end{array}$ \\
\hline Ograniczona (zmiany hiperpigmentacyjne) & $\begin{array}{l}\text { Hiperpigmentacja pozapalna, plamy typu café au lait, liszaj płaski indukowany } \\
\text { promieniowaniem słonecznym, erythema dyschromicum perstans }\end{array}$ \\
\hline Ograniczona (zmiany zanikowe) & Liszaj twardzinowy, blizny, zanikowe zapalenie skóry kończyn, lipodystrofia \\
\hline Uogólniona & $\begin{array}{l}\text { Twardzina układowa, mieszana choroba tkanki łącznej, GVHD, porfiria skórna późna, } \\
\text { scleredema adultorum (Buschkego), liszaj śluzowaty twardzinowy, nerkopochodna } \\
\text { dermopatia włókniejąca }\end{array}$ \\
\hline Linijna & $\begin{array}{l}\text { Lipodystrofia postępująca, lipoatrofia wywołana glikokortykosteroidami, lipoatrofia } \\
\text { umiejscowiona }\end{array}$ \\
\hline Głęboka & Zapalenie tkanki podskórnej, odmiana podskórna (głęboka) tocznia rumieniowatego \\
\hline
\end{tabular}

\section{HISTOPATHOLOGICAL EXAMINATION OF THE SKIN}

Skin biopsy from lesions to histopathological examination should be taken only in suspect cases with unclear clinical picture in order to make a diagnosis $[2,3,5]$. In case one of the mild LoSc clinical forms is suspected (plaque morphea, guttate morphea, atrophoderma of Pasini and Pierini) it is recommended to perform a punch biopsy (3$6 \mathrm{~mm}$ ), preferable from the area of grey and erythematous ridge $[2,3,5]$. In case a severe LoSc is suspected that includes extensive tissue involvement, a biopsy should be deep enough and include the subcutis (deep scleroderma, linear scleroderma, and generalized scleroderma) [32]. It should be emphasized that lesions observed in a histopathological examination correlate with the disease activity. At an early inflammatory phase of the disease, there are present thick collagen bundles in the reticular layer that are parallel to the skin surface and a thick inflammatory infiltration consisting mainly in lymphocytes and plasma cells (alternatively, monocytes, eosinophils), which are found between collagen bundles and round superficial and deep vessels niem do oceny ortopedycznej i zastosowania odpowiednich zabiegów fizjoterapii [3]. Czasami w przebiegu ciężkich postaci LoSc mogą się pojawić różne objawy pozaskórne, które przedstawiono w tabeli 2.

\section{DIAGNOSTYKA RÓŻNICOWA I PROCEDURY DIAGNOSTYCZNE}

Twardzina ograniczona wymaga różnicowania z chorobami, które wykazują podobieństwa w obrazie klinicznym. W tabeli 3 przedstawiono diagnostykę różnicową w zależności od postaci LoSc oraz fazy choroby $[1-3,5]$.

\section{BADANIE HISTOPATOLOGICZNE SKÓRY}

Wycinek skóry ze zmian chorobowych należy pobierać do badania histopatologicznego jedynie w sytuacjach wątpliwych, o niejasnym obrazie klinicznym, w celu ustalenia rozpoznania $[2,3,5]$. W przypadku podejrzenia jednej z postaci klinicznych LoSc o łagodnym przebiegu (twardzina plackowata, twardzina grudkowa, twardzina ograniczona pierwotnie zanikowa) zaleca się wykonanie 
[1]. The epidermis may by uninvolved, but more often it is thinned and smoothed. During a progressing phase, there appear hardenings and homogenization of collagen bundles, decrease in the number of vessels, and thickening/hyalinization of the wall of blood vessels [1]. A late phase includes closely packed collagen fibres, atrophy of skin adnexa and no inflammatory infiltrations. The subcutis is substituted with collagen fibres from the lowest reticular layer of the dermis and connective tissue septa [1]. Staining helpful in histological differential diagnostics of LoSc with scarring, lichen sclerosus, radiation-induced skin damage, connective tissue naevus, scleredema, and scleromyxedema includes orcein stain for elastic tissue, which are preserved in LoSc, trichrome stain for thickened collagen fibres, alcian blue stain for mucin, which is not confirmed in LoSc, or CD34 and factor XIII immunohistochemical staining that shows the loss of these markers in dendritic cells in the dermis in LoSc [33].

\section{LABORATORY TESTS}

Routine laboratory tests in LoSc-patients include peripherial complete blood count (CBC), erythrocyte sedimentation rate (ESR), and biochemical testing level demarcation of lactate dehydrogenase (LDH), creatinine kinase and aldolase (especially with signs of muscle involvements) [1-3, 5]. Peripheral blood eosinophilia is often confirmed in active phases of generalized localized scleroderma and linear scleroderma $[1-3,5]$. Increased parameters of inflammation are observed in an early active phase of the disease [1]. Active phase of linear localized scleroderma includes, especially in children, hypergammaglobulinemia and RF, which is sometimes associated with concomitant rheumatoid arthritis [1]. Despite the descriptions of co-existing various antibodies in LoSc-patients (ANA, anti-single-stranded DNA antibodies, against histones, topoisomerase II $\alpha$, anti-RNP antibodies, and against metalloproteinases) routine diagnostics for the presence of antinuclear antibodies (ANA) and antibodies against extractable nuclear antigens (ENA) is not recommended [1-3, 5]. Demarcation of ANA and ENA should be performed in questionable cases when systemic sclerosis is suspected [1-3,5]. Similarly, routine diagnostics for Lyme disease is not recommended. A set of laboratory tests recommended for patients with LoSc has been presented in table $4[1,2,14]$.

\section{METHODS FOR ASSESSMENT OF ACTIVITY/ INTENSITY OF THE DISEASE AND TISSUE DAMAGE}

In the clinical assessment of LoSc-patients the evaluation of disease activity and intensity (since biopsji sztancowej (3-6 mm), najlepiej z okolicy sinej, rumieniowej obwódki $[2,3,5]$. W przypadku podejrzenia LoSc o ciężkim przebiegu, z rozległym zajęciem tkanek powinno się pobrać dostatecznie głęboki wycinek zawierający tkankę podskórną (twardzina ograniczona głęboka, linijna i uogólniona) [32]. Warto podkreślić, że zmiany obserwowane w badaniu histopatologicznym korelują z aktywnością choroby. We wczesnej, zapalnej fazie choroby obecne są grube wiązki kolagenu w warstwie siateczkowatej biegnące równolegle do powierzchni skóry oraz gęsty naciek zapalny złożony głównie z limfocytów i komórek plazmatycznych (ewentualnie monocytów, eozynofilów), który lokalizuje się pomiędzy wiązkami kolagenu i wokół powierzchownych oraz głębokich naczyń [1]. Naskórek może być niezmieniony, ale częściej jest ścieńczały i wygładzony. W fazie postępującego stwardnienia dochodzi do pogrubienia i homogenizacji wiązek kolagenu, zmniejszenia liczby naczyń oraz pogrubienia lub hialinizacji ścian naczyń krwionośnych [1]. W fazie późnej obecne są ciasno upakowane włókna kolagenu, obserwuje się zanik przydatków skóry oraz brak nacieków zapalnych. Tkanka podskórna jest zastępowana włóknami kolagenu od najniżej położonych warstw skóry właściwej i przegród łącznotkankowych [1]. W histologicznej diagnostyce różnicowej należy różnicować LoSc z blizną, liszajem twardzinowym, popromiennym uszkodzeniem skóry, znamieniem łącznotkankowym, scleredema i scleremyxedema, pomocne są barwienia orceiną na włókna sprężyste, które w LoSc są zachowane, trichromem na pogrubiałe włókna kolagenu, błękitem alcjanu na obecność mucyny, której w LoSc się nie stwierdza, lub immunohistochemiczne CD34 i czynnikiem XIII wykazujące utratę tych markerów na komórkach dendrytycznych w skórze właściwej w LoSc [33].

\section{BADANIA LABORATORYJNE}

Rutynowe badania laboratoryjne u chorych na LoSc obejmują wykonanie morfologii krwi obwodowej, odczynu Biernackiego (OB) oraz badań biochemicznych oznaczenia stężenia dehydrogenazy mleczanowej (lactate dehydrogenase - LDH), kinazy kreatyninowej (CK) i aldolazy (zwłaszcza przy występowaniu objawów zajęcia mięśni) [1-3, 5]. W aktywnej fazie twardziny ograniczonej uogólnionej i linijnej stwierdza się często eozynofilię krwi obwodowej [1-3, 5]. Podwyższone parametry stanu zapalnego obserwuje się we wczesnej, aktywnej fazie choroby [1]. W aktywnej fazie postaci linijnej twardziny ograniczonej, szczególnie u dzieci, obserwuje się hipergammaglobulinemię oraz RF, który niekiedy związany jest z współwystępowaniem reumatoidalnego zapalenia stawów [1]. Pomimo opisów występowania różnych przeciwciał $u$ chorych na LoSc (ANA, przeciwko jednoniciowemu DNA, histonom, topoizomerazie II $\alpha$, przeciwko małym jądrowym rybonukleoproteinom oraz przeciwko metaloproteinazom), nie zaleca się rutynowej 
Table 4. Laboratory tests recommended in diagnostics of localized scleroderma [I, 2, I 4]

\begin{tabular}{|c|c|c|c|}
\hline Test type & Deviance & Clinical type of localized scleroderma/clinical phase & Comments \\
\hline Peripheral blood CBC & Eosinophilia & Active phase of linear scleroderma and generalized localized scleroderma & \\
\hline \multirow[t]{4}{*}{ Biochemical tests } & $\mathrm{LDH}$ & \multirow{3}{*}{$\begin{array}{l}\text { Linear scleroderma, generalized localized scleroderma, disabling } \\
\text { pansclerotic scleroderma, deep scleroderma }\end{array}$} & \multirow[t]{3}{*}{ Muscle symptoms } \\
\hline & CK & & \\
\hline & Aldolase & & \\
\hline & ESR & Active phase & \\
\hline Other & RF & $\begin{array}{l}\text { Linear scleroderma, generalized localized scleroderma, disabling } \\
\text { pansclerotic scleroderma }\end{array}$ & $\begin{array}{l}\text { Osteoarticular } \\
\text { symptoms }\end{array}$ \\
\hline
\end{tabular}

Tabela 4. Badania laboratoryjne zalecane w diagnostyce twardziny ograniczonej [I, 2, I4]

\begin{tabular}{|c|c|c|c|}
\hline Rodzaj badania & Odchylenia & Postać kliniczna twardziny ograniczonej lub faza kliniczna & Uwagi \\
\hline Morfologia krwi obwodowej & Eozynofilia & Faza aktywna twardziny linijnej i twardziny ograniczonej uogólnionej & \\
\hline \multirow[t]{4}{*}{ Badania biochemiczne } & $\mathrm{LDH}$ & \multirow{3}{*}{$\begin{array}{l}\text { Twardzina linijna, twardzina ograniczona uogólniona, } \\
\text { disabling pansclerotic scleroderma, twardzina glęboka }\end{array}$} & \multirow[t]{3}{*}{ Objawy mięśniowe } \\
\hline & CK & & \\
\hline & Aldolaza & & \\
\hline & $\mathrm{OB}$ & Faza aktywna & \\
\hline Inne & RF & $\begin{array}{l}\text { Twardzina linijna, twardzina ograniczona uogólniona, } \\
\text { disabling pansclerotic scleroderma }\end{array}$ & $\begin{array}{l}\text { Objawy kostno- } \\
\text {-stawowe }\end{array}$ \\
\hline
\end{tabular}

it exerts an influence on the choice of a proper therapy) as well as the level of tissue damage is important. In 2009 Localized Scleroderma Clinical and Ultrasound Study Group proposed and initially validated an LS Skin Severity Index (LoSSI) and LS Skin Damage Index (LoSDI) [34-36]. Both indexes are based on the assessment of various dermatological parameters in 18 autonomous areas [34-36]. According to the recommendation of this group, the above indexes should be used together with physician's global assessment (PGA) [34-36]. A combination of LoSSI and LoSDI is called LS Cutaneous Assessment Tool (LoSCAT) [34-36]. LoSCAT is characterized by repeatability and correspondence of results, as well as sensitivity to changes resulting from the used treatment $[2,37]$. Limitations of the above-mentioned questionnaire result from the time-consuming nature of the test and lack of consideration for extracutaneous manifestations (involvement of the CNS, sight organ, muscles, joints), which constitute one of the indexes for tissue damage during the disease course.

\section{IMAGING}

Clinical assessment of severe cases of patients suffering from linear scleroderma (en coup de sabre and progressive facial hemiatrophy) requires imaging examinations - MRI and computed tomography (CT) of the head and facial skeleton $[1,2,8]$. MRI should be performed upon diagnosing ECDS. It is recommended to repeat the listed examinations in case neurological symptoms appear [32]. Less common meth- diagnostyki w kierunku obecności przeciwciał przeciwjądrowych (antinuclear antibodies - ANA) oraz przeciwciał przeciwko rozpuszczalnym antygenom jądrowym (extractable nuclear antigens - ENA) [1-3, 5]. Oznaczenia ANA i ENA należy wykonać w przypadkach wątpliwych przy podejrzeniu twardziny układowej [1-3, 5]. Nie zaleca się też rutynowej diagnostyki w kierunku boreliozy. Zestawienie badań laboratoryjnych zalecanych $\mathrm{w}$ diagnostyce pacjenta $\mathrm{z}$ LoSc przedstawiono $\mathrm{w}$ tabeli 4 $[1,2,14]$.

\section{METODY OCENY AKTYWNOŚCI LUB NASILENIA CHOROBY ORAZ USZKODZENIA TKANEK}

W ocenie klinicznej chorych na LoSc ważna jest ocena aktywności i nasilenia choroby (co wpływa na wybór odpowiedniej terapii) oraz stopnia uszkodzenia tkanek. W 2009 roku Kliniczna i Ultrasonograficzna Grupa Badawcza Twardziny Ograniczonej (Localized Scleroderma Clinical and Ultrasound Study Group) zaproponowała i wstępnie zwalidowała wskaźnik aktywności lub nasilenia choroby (LS Skin Severity Index - LoSSI) oraz wskaźnik uszkodzenia tkanek (LS Skin Damage Index - LoSDI) [34-36]. Oba wskaźniki opierają się na ocenie różnych parametrów dermatologicznych w 18 lokalizacjach anatomicznych [34-36]. Zgodnie z rekomendacjami tej grupy powyższe indeksy należy stosować w połączeniu z ogólną oceną lekarską (physican's global assessment - PGA) [34-36]. Kombinacja wskaźników LoSSI i LoSDI nosi nazwę LS Cutaneous Assessement Tool (LoSCAT) [34-36]. Wskaźnik LoSCAT cechuje się powtarzalnością i zgodnością ocen, a także czułością na zmiany wyni- 
ods of disease activity/intensity assessment include: ultrasound, electromyography, thermography, laser Doppler flowmetry, and durometry [38-40].

\section{TREATMENT OF LOCALIZED SCLERODERMA}

A therapeutic decision in case of LoSc-patients should depend on clinical type of the disease, assessment of the disease activity/intensity, depth and extent of lesions, and assessment of tissue damage signs. Individual active dermis-bound plaques of LoSc may require an introduction of local treatment with glucocorticosteroids (GCS) or calcineurin inhibitors. It is recommended to apply high potency GCS (once a day for a month) or moderate potency GCS (once a day for 3 months), with or without occlusion dressing [1, 2]. In case there are no sufficient therapeutic effects, the treatment may be continued with intervals. Calcineurin inhibitors - tacrolimus and pimecrolimus - are recommended as therapy alternative to GCS in treatment of active plaque morphea. The preparations should be used twice a day for 23 months (with or without occlusion dressing) [1-3, $32,41]$. In case of small active lesions with signs of hardening and involvement of deeper tissues, intralesional injections of triamcinolone in the dose of 10 $40 \mathrm{mg} / \mathrm{ml}$ (alternatively with lidocaine), which should be repeated once a week for about 3 weeks, may be applied $[1,2]$. An active inflammatory ridge of eruptions is a recommended site for injections.

Vitamin $\mathrm{D}_{3}$ derivatives (calcipotriol), similarly to calcineurin inhibitors, are drugs alternative to GCS in the treatment of active plaque morphea foci that spread superficially $[1,2] .0 .005 \%$ calcipotriol may be effective both in monotherapy and in combination with betamethasone dipropionate. A recommended treatment regimen includes application twice a day for a minimum of 3 months, best if applied under an occlusive dressing $[1,2,42]$.

In case the above methods are not successful, a phototherapy (3-5 times a week, 30-50 radiations) should be considered [1-3]. UVA (320-400 nm), UVA1 (340-400 nm), or UVB (280-320 nm) therapy may be used. Detailed guidelines of Polish Dermatological Society regarding the phototherapy are discussed in another paper. A combination of phototherapy and local treatment with GCS and vitamin $\mathrm{D}_{3}$ derivatives brings good therapeutic results [1]. UVA1 phototherapy, 340-400 nm wavelength, is believed to be the best form of the light treatment in LoSc, but it is almost unavailable in Polish conditions [43]. A retrospective study conducted on a group of 11 patients with localized scleroderma showed a comparable efficacy of various forms of phototherapy (PUVA-bath, PUVA-soak, UVB-311 nm) both upon clinical and ultrasound assessment [44]. The PUVA kające z zastosowanego leczenia $[2,37]$. Ograniczenia powyższego kwestionariusza wynikają z czasochłonności badania oraz nieuwzględnienia objawów pozaskórnych (zajęcie OUN, narządu wzroku, mięśni, stawów), które stanowią jeden z wykładników uszkodzenia tkanek w przebiegu choroby.

\section{BADANIA OBRAZOWE}

Ocena kliniczna ciężkich przypadków pacjentów z odmianą linijną twardziny ograniczonej (typu cięcia szablą i postępującego zaniku połowiczego twarzy) wymaga wykonania badań obrazowych - MRI, tomografii komputerowej (computed tomography - CT) głowy i twarzoczaszki $[1,2,8]$. Badanie MRI należy wykonać $\mathrm{w}$ chwili postawienia diagnozy ECDS. Rekomenduje się powtórzenie wymienionych badań w przypadku wystąpienia objawów neurologicznych [32]. Do rzadziej stosowanych metod oceny aktywności lub nasilenia choroby należą: ultrasonografia, elektromiografia, termografia, laserowy przepływomierz dopplerowski, durometria [38-40].

\section{LECZENIE TWARDZINY OGRANICZONEJ}

Decyzje terapeutyczne $u$ chorych na LoSc powinny uwzględniać postać kliniczną choroby, jej aktywność lub nasilenie, głębokość i rozległość zmian, a także cechy uszkodzenia tkanek. Pojedyncze, aktywne, ograniczone do skóry właściwej blaszki LoSc mogą być wskazaniem do wdrożenia terapii miejscowej glikokortykosteroidami (GKS) lub inhibitorami kalcyneuryny. Rekomenduje się aplikację GKS o dużej (1 raz dziennie przez 1 miesiąc) lub umiarkowanej (1 raz dziennie przez 3 miesiące) sile działania, z okluzją lub bez okluzji [1, 2]. W przypadku niewystarczającego efektu leczniczego kurację można kontynuować w formie przerywanej. Inhibitory kalcyneuryny - takrolimus lub pimekrolimus - są zalecane jako terapia alternatywna wobec GSK w leczeniu aktywnej twardziny plackowatej. Preparaty należy stosować 2 razy dziennie przez 2-3 miesiące (z okluzją lub bez okluzji) [1-3, 32, 41]. W przypadku małych, aktywnych zmian z cechami stwardnienia i zajęcia tkanek głębiej położonych można zastosować doogniskowe iniekcje triamcynolonu w dawce 10-40 mg/ml (ewentualnie z lidokainą), które należy powtarzać raz w tygodniu przez około 3 tygodnie [1, 2]. Zalecanym miejscem iniekcji jest aktywny, zapalny brzeg wykwitów.

Pochodne witaminy $\mathrm{D}_{3}$ (kalcypotriol), podobnie jak inhibitory kalcyneuryny, to leki alternatywne wobec GKS w terapii aktywnych ognisk twardziny plackowatej szerzącej się powierzchownie [1, 2]. Kalcypotriol 0,005\% może być skuteczny zarówno w monoterapii, jak i w połączeniu z dipropionianem betametazonu. Zalecany 
method is popular in Poland. The largest published prospective cohort study (63 LoSc-patients) showed a similar therapeutic effect of every out of the three doses $\left(5,10,20 \mathrm{~J} / \mathrm{cm}^{2}\right)$ after 20 cycles of radiation $[1,2]$. So far there have been no analyses comparing PUVA with other light treatment methods in LoSc $[1,2]$. The therapy with PUVA is most successful in the treatment of active inflammatory foci of LoSc during early stages of the disease. It is recommended to perform the procedures 3-5 times a week, with a total number of at least $30[1,2]$.

Photodynamic therapy (PDT) is based on the utilization of a phototoxic reaction that occurs as a result of photosensitizer (most often $5 \%$ aminolevulinic acid) influencing the light with the $630 \mathrm{~nm}$ wavelength. Therapeutic properties of PDT result from its anti-inflammatory activity and inhibition of a fibrotic process by increasing the production of metalloproteinases $[45,46]$. There was no disease progression or recurrence observed in patients who underwent PDT during a 2-year control after the treatment ended [46].

In case of progressive plaque morphea an introduction of systemic therapy should be considered. It should be highlighted that its early introduction is important in patients with active/intensified generalized localized scleroderma, disabling pansclerotic scleroderma, all types of linear scleroderma, as well as deep and mixed scleroderma.

It is recommended to use oral or subcutaneous methotrexate in the dose of 15-25 mg/week. Methotrexate may used in combination with GCS (prednisone $0.5-1 \mathrm{mg} / \mathrm{kg} /$ day orally for 3-4 months, or methylprednisolone $30 \mathrm{mg} / \mathrm{kg} /$ day - max. 1,000 g/ day IV for 3 subsequent days a month during subsequent 3-6 months) [1-3]. Methotrexate should be used till the disease remission, from several months to 2 years, and then, gradually reduce the drug dose $[3,47,48]$. Methotrexate is the best tested recommended drug in general therapy for LoSc. The newest reports have showed a remission in $26 \%$ of patients after a year of methotrexate treatment, and in $63 \%$ of patients after 2 years of treatment (a study group 107 individuals) [47]. Nevertheless, there have also been disease recurrences after 4-20 months after the end of methotrexate treatment (the therapy lasted from 27.5 to 36 months) [48].

In case of contraindications or methotrexate intolerance, including mycophenolate mofetil (MMF) in the dose of 1-2 g/day should be considered. A beneficial safety profile was showed till the dose of $3 \mathrm{~g} /$ day. Mycophenolate mofetil is a cytostatic drug that inhibits proliferation of lymphocytes, fibroblasts, and myocytes. In 2009 results of a study, which assessed efficacy of MMF (in the oral dose of $600-1,200 \mathrm{mg} /$ $\mathrm{m}^{2}$, twice a day) in a group of 10 children with severe LoSc resistant to combined treatment including GCS schemat kuracji obejmuje aplikację 2 razy dziennie przez minimum 3 miesiące, najlepiej pod okluzją $[1,2,42]$.

W przypadku nieskuteczności powyższych metod należy rozważyć rozpoczęcie fototerapii (3-5 razy na tydzień, łącznie 30-50 naświetlań) [1-3]. Można zastosować terapię UVA (320-400 nm), UVA1 (340-400 nm) lub UVB (280-320 nm). Szczegółowe rekomendacje Polskiego Towarzystwa Dermatologicznego dotyczące fototerapii są przedmiotem odrębnego opracowania. Dobre efekty terapeutyczne może przynieść połączenie fototerapii z leczeniem miejscowym, np. GKS lub pochodnymi witaminy $\mathrm{D}_{3}$ [1]. Fototerapia UVA1 o długości fali 340-400 nm jest najlepiej ocenianą formą światłolecznictwa w LoSc, ale w polskich warunkach o bardzo ograniczonej dostępności [43]. W badaniu retrospektywnym przeprowadzonym u 11 chorych z LoSc stwierdzono porównywalną skuteczność różnych metod fototerapii (PUVA-bath, PUVA-soak, UVB-311 nm), zarówno w ocenie klinicznej, jak i ultrasonograficznej [44]. Szeroko stosowana w Polsce jest metoda PUVA. W największym opublikowanym prospektywnym badaniu kohortowym (63 pacjentów z LoSc) wykazano zbliżony efekt terapeutyczny każdej $\mathrm{z}$ trzech dawek $\left(5,10,20 \mathrm{~J} / \mathrm{cm}^{2}\right)$ po zakończeniu cyklu 20 naświetlań $[1,2]$. Dotychczas nie przeprowadzono analiz porównujących PUVA z innymi metodami światłolecznictwa w LoSc [1, 2]. Największą skuteczność PUVA-terapii uzyskuje się w leczeniu aktywnych, zapalnych ognisk LoSc we wczesnej fazie choroby. Zaleca się wykonywanie naświetlań z częstością 3-5 razy tygodniowo, w łącznej liczbie co najmniej 30 [1, 2].

Terapia fotodynamiczna (photodynamic therapy - PDT) polega na wykorzystaniu reakcji fototoksycznej, która zachodzi w wyniku oddziaływania fotouczulacza (najczęściej 5\% kwasu 5-aminolewulinowego (ALA)) ze światłem o długości fali $630 \mathrm{~nm}$. Właściwości terapeutyczne PDT wynikają z działania przeciwzapalnego oraz hamowania procesu włóknienia poprzez zwiększenie produkcji metaloproteinaz $[45,46]$. U pacjentów, u których stosowano PDT, nie obserwowano progresji ani nawrotu choroby w czasie 2-letniej obserwacji po zakończeniu leczenia [46].

W przypadku postępującej twardziny plackowatej należy rozważyć włączenie terapii ogólnej. Warto podkreślić, że odpowiednio wczesne jej wdrożenie jest istotne $\mathrm{u}$ chorych $\mathrm{z}$ aktywną lub nasiloną twardziną ograniczoną uogólnioną, twardziną uogólnioną zniekształcającą, wszystkimi odmianami twardziny linijnej, postaci głębokiej i mieszanej choroby.

Zaleca się stosowanie metotreksatu w dawkach 15$25 \mathrm{mg}$ tygodniowo doustnie lub podskórnie. Metotreksat można stosować w połączeniu z GKS (np. prednizon w dawce $0,5-1 \mathrm{mg} / \mathrm{kg}$ m.c./ dobę doustnie przez 3-4 miesiące lub z metyloprednizolonem w dawce $30 \mathrm{mg} /$ kg m.c./dobę - maks. $1000 \mathrm{~g} /$ dobę - dożylnie przez 3 kolejne dni w miesiącu w czasie kolejnych 3-6 miesięcy) [1-3]. Metotreksat należy stosować do uzyskania 
with methotrexate, were published [49]. In 9 out of 10 cases a decrease in tenacity of the foci was confirmed, whereas in 7 out of 10 patients a reduction in the number of inflammatory lesions was noted. MMF adverse reactions were not confirmed in any of the cases [49].

Vascular drugs (pentoxifylline, sulodexide) improve vascular flow and rheological properties of blood cells, and prevent dysfunctions of endothelial cells, and may used as a therapy supporting immunosuppressive treatment [50]. Pentoxifylline has anti-inflammatory, fibrinolytic and anti-oxidative activity. It induces prostacyclin synthesis and decreases adhesion and aggregation of blood platelets [51]. Pentoxifylline may be used orally in the dose of $400 \mathrm{mg}$ twice or three times a day or intravenously in the dose of 150-300 mg/day. Sulodexide has antithrombotic properties that result from activation of the fibrinolytic system and inhibition of platelet aggregation and factor $\mathrm{Xa}$; moreover, it exerts anti-inflammatory and protective influence on the vascular endothelium $[52,53]$. It is recommended to take an oral dose of $500 \mathrm{LSU} /$ day in two divided doses, and then once 250 LSU/day or IV in the dose of 600-1,200 LSU/ day $[53,54]$. Pentoxifylline, similarly to sulodexide, intensifies the effects of antithrombotic drugs, and in addition, it may interact with hypotensive and anti-diabetic preparations [51].

Antibiotics (penicillin, ceftriaxone) are not currently recommended as a standard in the therapy of LoSc due to a questionable association of LoSc with $B$. burgdorferi infection $[1,5,32]$. Some experts indicate that response of LoSc to antibiotics therapy may be connected to the influence of antibiotics to concomitant infection foci or their immunosuppressive activity.

Recent reports indicate the efficacy of systemic calcineurin inhibitors (cyclosporine (CsA) and tacrolimus) used orally in the therapy of severe cases of loSc. Bali et al. used CsA in an average dose of $2.4 \mathrm{mg} /$ $\mathrm{kg} /$ day in a group of 12 LoSc-patients (9 - generalized type, 2 - linear localized type, 1 - progressive facial hemiatrophy) and show good therapeutic effects of CsA already after 1-2 months of the therapy (total response to treatment in 5/12 of the patients; partial 6/12) [55]. After 18.6 months the extent of disease foci (body surface area - BSA) decreased from 50\% to $17 \%$ [55]. The authors suggest that CsA administered at an early phase of the disease may prevent progressive tissue fibrosis and appearance of joint contractures. It should be emphasized that immunosuppressive treatment in LoSc-patients requires, depending on the drug used, proper monitoring during the therapy and performance of recommended laboratory tests.

There were individual cases of effective use of other vasodilators (e.g. prostanoids), classic immu- remisji choroby od kilku miesięcy do 2 lat, a następnie stopniowo redukować jego dawkę [3, 47, 48]. Metotreksat jest najlepiej zbadanym, zalecanym lekiem w terapii ogólnej LoSc. Najnowsze doniesienia wykazały remisję u $26 \%$ chorych po roku leczenia metotreksatem, a u 63\% pacjentów po 2 latach leczenia (grupa badana - 107 osób) [47]. Odnotowano jednak nawroty choroby po 4-20 miesiącach od zakończenia kuracji metotreksatem (czas trwania terapii wynosił 27,5-36 miesięcy) [48].

W przypadku przeciwwskazań lub nietolerancji metotreksatu należy rozważyć włączenie mykofenolanu mofetylu (MMF) w dawce 1-2 g/dobę. Stwierdzono korzystny profil bezpieczeństwa dawki do $3 \mathrm{~g} /$ dobę. Mykofenolan mofetylu jest lekiem cytostatycznym, który hamuje proliferację limfocytów, fibroblastów i miocytów. W 2009 roku opublikowano wyniki badania, w którym oceniano skuteczność MMF (w dawce $600-1200 \mathrm{mg} / \mathrm{m}^{2}$ 2 razy dziennie doustnie) u 10 dzieci z LoSc o ciężkim przebiegu, oporną na leczenie skojarzone GKS z metotreksatem [49]. U 9 spośród 10 pacjentów wykazano redukcję spoistości ognisk, a u 7 stwierdzono zmniejszenie liczby zmian zapalnych. W żadnym przypadku nie odnotowano działań niepożądanych MMF [49].

Leki naczyniowe (pentoksyfilina, sulodeksyd) poprawiają przepływ naczyniowy i właściwości reologiczne krwinek, a także zapobiegają dysfunkcji komórek śródbłonka i mogą być stosowane jako terapia wspomagająca leczenie immunosupresyjne [50]. Pentoksyfilina ma działanie przeciwzapalne, fibrynolityczne i antyoksydacyjne. Indukuje syntezę prostacykliny, a także zmniejsza adhezję i agregację płytek krwi [51]. Pentoksyfilina może być stosowana doustnie w dawce $400 \mathrm{mg}$ 2-3 razy na dobę lub dożylnie w dawce 150-300 mg/dobę. Sulodeksyd ma właściwości przeciwzakrzepowe, które wynikają z aktywacji układu fibrynolitycznego oraz hamowania agregacji płytek i czynnika Xa; ponadto działa przeciwzapalnie i protekcyjnie na śródbłonek naczyń $[52,53]$. Zaleca się przyjmowanie leku doustnie w dawce 500 LSU/dobę w dwóch dawkach podzielonych, a następnie 1 raz w dawce 250 LSU/dobę lub dożylnie w dawce 600-1200 LSU/dobę [53, 54]. Pentoksyfilina, podobnie jak sulodeksyd, nasila działanie leków przeciwzakrzepowych, a dodatkowo może wchodzić w interakcje z preparatami hipotensyjnymi i przeciwcukrzycowymi [51].

Antybiotyki (penicylina, ceftriakson) nie są obecnie standardowo rekomendowane w terapii LoSc ze względu na wątpliwy związek tej choroby z infekcją B. burgdorferi $[1,5,32]$. Niektórzy eksperci wskazują, że przypadki odpowiedzi LoSc na antybiotykoterapię mogą być związane z oddziaływaniem antybiotyków na współistniejące ogniska infekcji lub ich działaniem immunosupresyjnym.

Najnowsze doniesienia wskazują na skuteczność stosowanych ogólnie inhibitorów kalcyneuryny (cyklosporyny (CsA) i takrolimusu) w terapii ciężkich odmian LoSc. Bali i wsp. stosowali CsA w średniej dawce 2,4 mg/kg m.c./dobę u 12 pacjentów z LoSc (9 - postać 
nosuppressive drugs (e.g. azathioprine), biological drugs (e.g. rituximab, tocilizumab), and Janus kinase inhibitors (e.g. tofacitinib), as well as IV immunoglobulins in patients with LoSc. However, currently there are no clinical studies that would assess the efficacy and safety of those therapeutic methods in a larger number of patients [1].

Physical therapy is of key importance in the treatment of LoSc with a severe disabling course, and also the deep, linear, generalized, and mixed types [1, 2]. Rehabilitation should be introduced early enough to prevent irreversible orthopaedic complications such as contractures, limitations in joint mobility or growth disorders that affect about $30-50 \%$ of patients with linear localized scleroderma $[5,32]$. The importance of physical therapy in the treatment of linear LoSc was highlighted already in 1976 [56]. Rudolph and Leyden presented promising study results and draw attentions to availability of rehabilitation procedures, low costs, and no adverse reactions as compared with systemic therapies $[8,56]$. It should be emphasized that physical therapy be used only in non-active stationary phase of the disease and should be implemented directly after restraining the active form of the disease, with the frequency of once-twice a week 3 months, among others [1, 2]. The most recent reports show that sclerotic foci react to massage uogólniona, 2 - linijna kończyn, 1 - postępujący zanik połowiczy twarzy) i wykazali dobry efekt terapeutyczny CsA już po 1-2 miesiącach terapii (całkowita odpowiedź na leczenie u 5 spośród 12 pacjentów, częściowa - 6 spośród 12) [55]. Po 18,6 miesiąca rozległość ognisk chorobowych (body surface area - BSA) zmniejszyła się z 50\% do $17 \%$ [55]. Autorzy sugerują, że CsA podana we wczesnej fazie choroby może zapobiegać postępującemu włóknieniu tkanek i pojawianiu się przykurczów stawowych. Prowadzenie leczenia immunosupresyjnego u chorych na LoSc wymaga, w zależności od zastosowanego leku, odpowiedniego monitorowania $\mathrm{w}$ trakcie terapii oraz wykonywania zalecanych badań laboratoryjnych.

U pacjentów z LoSc opisano pojedyncze przypadki skutecznego zastosowania innych leków rozszerzających naczynia (np. prostanoidów), klasycznych leków immunosupresyjnych (np. azatiopryny), leków biologicznych (np. rytuksymabu, tocilizumabu) oraz inhibitorów kinaz janusowych (np. tofacytynibu), a także dożylnych immunoglobulin u pacjentów z LoSc. Nie ma jednak obecnie badań klinicznych oceniających skuteczność i bezpieczeństwo tych metod terapeutycznych w większej grupie pacjentów [1].

Fizjoterapia jest bardzo ważna w leczeniu LoSc o ciężkim, okaleczającym przebiegu, a także postaci głębokiej, linijnej, uogólnionej i mieszanej [1, 2]. Rehabilitacja powinna być wdrażana odpowiednio wcześnie, aby zapobiec nieodwracalnym powikłaniom ortopedycznym, ta-

Table 5. Regimen for therapeutic procedures in localized scleroderma depending on the clinical form in adults [I, 2]

\begin{tabular}{|c|c|c|c|}
\hline Drug & $\begin{array}{l}\text { Localized plaque } \\
\text { morphea }\end{array}$ & $\begin{array}{l}\text { Linear localized scleroderma, deep scleroderma, } \\
\text { mixed scleroderma, progressive plaque morphea }\end{array}$ & Generalized localized scleroderma \\
\hline $\begin{array}{l}\text { First- } \\
\text { choice }\end{array}$ & $\begin{array}{l}\text { Glucocorticosteroids } \\
\text { (topically): } \\
\text { - High potency: once } \\
\text { a day, up to a month } \\
\text { - Moderate potency: } \\
\text { once a day, up to } \\
3 \text { months }\end{array}$ & $\begin{array}{l}\text { MTX + glucocorticosteroids (systemically): } \\
\text { - MTX: I 5-25 mg/week (adults) I } 5 \text { mg/m²/week } \\
\text { (children) } \\
\text { - Prednisone: } 0.5 \text { - I mg/kg/day in } 2 \text { divided doses } \\
\text { for 2-4 weeks, with gradual dose reduction } \\
\text { - Methylprednisolone: } 30 \mathrm{mg} / \mathrm{kg} / \text { day (max. I,000 } \\
\text { mg) for } 3 \text { consecutive days in a month, 3-6 } \\
\text { pulses IV }\end{array}$ & $\begin{array}{l}\text { Phototherapy : } \\
\text { - UVA: } 3 \text { times a week, } 50-80 \mathrm{~J} / \mathrm{cm}^{2} \text {, } \\
\text { about } 40 \text { procedures } \\
\text { - PUVA: } 2 \text {-4 times a week, about } \\
30 \text { procedures }\end{array}$ \\
\hline $\begin{array}{l}\text { Second- } \\
\text { choice }\end{array}$ & $\begin{array}{l}\text { Calcineurin inhibitors } \\
\text { (topically) }\end{array}$ & MMF I-2 g/day & $\begin{array}{l}\text { MTX + glucocorticosteroids (systemically): } \\
\text { - MTX: I 5-25 mg/week (adults) I } 5 \mathrm{mg} / \mathrm{m}^{2} / \\
\text { week (children) } \\
\text { - Prednisone: } 0.5 \text { - I mg/kg/day w } 2 \text { in } \\
2 \text { divided doses for 2-4 weeks, with } \\
\text { gradual dose reduction } \\
\text { - Methylprednisolone: } 30 \mathrm{mg} / \mathrm{kg} / \text { day (max. } \\
\text { I,000 mg) for } 3 \text { consecutive days in } \\
\text { a month, 3-6 pulses IV }\end{array}$ \\
\hline $\begin{array}{l}\text { Third- } \\
\text { choice }\end{array}$ & $\begin{array}{l}\text { Vitamin } \mathrm{D}_{3} \text { derivatives } \\
\text { (topically)/phototherapy } \\
\text { - Vitamin } \mathrm{D}_{3} \text { derivatives } \\
\text { - UVA: } 3 \text { times a week, } \\
\text { 50-80 J/cm², about } \\
40 \text { procedures } \\
\text { - PUVA: } 2 \text {-4 times } \\
\text { a week, about } \\
30 \text { procedures }\end{array}$ & & $\begin{array}{l}\text { MMF I-2 g/day } \\
\text { CsA } 3 \mathrm{mg} / \mathrm{kg}\end{array}$ \\
\hline
\end{tabular}


Tabela 5. Schemat postępowania terapeutycznego w twardzinie ograniczonej w zależności od postaci klinicznej u dorosłych [I, 2]

\begin{tabular}{|c|c|c|c|}
\hline Lek & Twardzina ograniczona plackowata & $\begin{array}{c}\text { Twardzina ograniczona linijna, głęboka, } \\
\text { mieszana, postępująca twardzina } \\
\text { ograniczona plackowata }\end{array}$ & $\begin{array}{c}\text { Twardzina ograniczona } \\
\text { uogólniona }\end{array}$ \\
\hline I wyboru & $\begin{array}{l}\text { GKS (miejscowo): } \\
\text { - Duża siła działania: I raz dziennie } \\
\text { do I miesiąca } \\
\text { - Umiarkowana siła działania: I raz } \\
\text { dziennie do } 3 \text { miesięcy }\end{array}$ & $\begin{array}{l}\text { MTX + GKS (ogólnie): } \\
\text { - MTX: I5-25 mg/tydz. (dorośli) I } 5 \text { mg/ } \\
\text { m² p.c./tydz. (dzieci) } \\
\text { - Prednizon: 0,5-I mg/kg m.c./dobę } \\
\text { w } 2 \text { dawkach podzielonych przez 2-4 tygo- } \\
\text { dnie, ze stopniową redukcją dawki } \\
\text { - Metyloprednizolon: } 30 \text { mg/kg m.c./dobę } \\
\text { (maks. I000 mg) przez } 3 \text { kolejne dni } \\
\text { w miesiącu, 3-6 pulsów i.v. }\end{array}$ & $\begin{array}{l}\text { Fototerapia: } \\
\text { - UVA: } 3 \text { razy tygodniowo, 50- } \\
80 \mathrm{~J} / \mathrm{cm}^{2} \text {, ok. } 40 \text { naświetlań } \\
\text { - PUVA: 2-4 razy tygodniowo, } \\
\text { ok. } 30 \text { naświetlań }\end{array}$ \\
\hline Il wyboru & $\begin{array}{l}\text { Inhibitory kalcyneuryny (miejscowo) } \\
\text { I-2 razy dziennie przez } 3 \text { miesiące }\end{array}$ & MMF I-2 g/dobę & $\begin{array}{l}\text { MTX + GKS (ogólnie): } \\
\text { - MTX: I5-25 mg/tydz. } \\
\text { (dorośli) I } 5 \text { mg/m² p.c./tydz. } \\
\text { (dzieci) } \\
\text { - Prednizon: 0,5-I mg/ } \\
\text { kg m.c./dobę w } 2 \text { dawkach } \\
\text { podzielonych przez 2-4 } \\
\text { tygodnie, ze stopniową } \\
\text { redukcją dawki } \\
\text { - Metyloprednizolon: } 30 \text { mg/ } \\
\text { kg m.c./dobę (maks. I000 mg) } \\
\text { przez 3 kolejne dni } \\
\text { w miesiącu, 3-6 pulsów i.v. }\end{array}$ \\
\hline $\begin{array}{l}\text { III } \\
\text { wyboru }\end{array}$ & $\begin{array}{l}\text { Pochodne witaminy } \mathrm{D}_{3} \text { (miejscowo)/ } \\
\text { fototerapia: } \\
\text { - Pochodne witaminy } \mathrm{D}_{3}: \text { I-2 razy } \\
\text { tygodniowo } \\
\text { - UVA: } 3 \text { razy w tygodniu, 50- } \\
80 \mathrm{~J} / \mathrm{cm}^{2} \text {, ok. } 40 \text { naświetlań } \\
\text { - PUVA: 2-4 razy w tygodniu, } \\
\text { ok. } 30 \text { naświetlań }\end{array}$ & & $\begin{array}{l}\text { MMF I-2 g/dobę } \\
\text { CsA } 3 \text { mg/kg m.c. }\end{array}$ \\
\hline
\end{tabular}

and lymphatic drainage [1,2]. The use of recommended therapies is presented in table 5 .

It is worth noting that non-active lesions, e.g. hyperpigmentation patches or skin and subcutis atrophy, that are results of tissue damage caused by an earlier disease process and have not been active for at least 6 months, do not require pharmacological treatment [3].

\section{CONCLUSIONS}

A patient affected by LoSc requires proper clinical assessment of the disease activity and intensity that condition individually-adjusted therapy depending on the clinical type of the disease as well as its intensity and activity. Immunosuppressive therapies should be introduced early and long enough to reach a non-active phase of the disease and subsiding of scleroses.

Guidelines of Polish Dermatological Society were prepared in order to facilitate diagnostic and therapeutic procedures in patients suffering from LoSc for Polish dermatologists and venereologists. In every case it is a physician who decides about the proce- kim jak przykurcze, ograniczenie ruchomości w stawach czy zaburzenia wzrostu, które dotyczą około 30-50\% chorych z twardziną linijną kończyn [5, 32]. Znaczenie zabiegów fizjoterapeutycznych $w$ procesie leczenia postaci linijnej LoSc podkreślano już w 1976 roku [56]. Rudolph i Leyden. przedstawili obiecujące wyniki badań, a także zwrócili uwagę na dostępność zabiegów rehabilitacyjnych, niskie koszty oraz brak działań niepożądanych w porównaniu z leczeniem ogólnym $[8,56]$. Zabiegi fizjoterapeutyczne mogą być wykonywane jedynie w nieaktywnej, stacjonarnej fazie choroby i powinny być wdrożone zaraz po opanowaniu aktywnej postaci LoSc. Prowadzi się je $z$ częstością 1-2 razy w tygodniu przez 3 miesiące [1, 2]. Najnowsze doniesienia wskazują, że ogniska stwardnienia dobrze reagują na masaż i drenaż limfatyczny $[1,2]$. Rekomendowane terapie przedstawiono w tabeli 5.

Warto zauważyć, że zmiany nieaktywne, takie jak plamy hiperpigmentacyjne lub atrofia skóry i tkanki podskórnej będące efektem uszkodzenia tkanek wcześniejszym procesem chorobowym i niewykazujące aktywności co najmniej przez 6 miesięcy, nie wymagają leczenia farmakologicznego [3]. 
dure after a thorough analysis of a patient's medical history, clinical picture, and results of additional tests. Therapeutic solutions presented in this paper do not recommend any specific products or manufacturers.

\section{CONFLICT OF INTEREST}

The authors declare no conflict of interest.

\section{PODSUMOWANIE}

Pacjent z LoSc wymaga odpowiedniej oceny klinicznej pod kątem aktywności oraz nasilenia procesu chorobowego, która warunkuje zastosowanie indywidualnie dobranej terapii, w zależności od postaci klinicznej oraz nasilenia i aktywności choroby. Terapię immunosupresyjną należy wdrażać wcześnie i stosować odpowiednio długo - do uzyskania braku aktywności choroby i ustępowania stwardnień.

Rekomendacje Polskiego Towarzystwa Dermatologicznego zostały opracowane w celu ułatwienia polskim dermatologom-wenerologom postępowania diagnostycznego i terapeutycznego u pacjentów z LoSc. W każdym przypadku o postępowaniu decyduje jednak lekarz po szczegółowej analizie wywiadu, obrazu klinicznego oraz wyników badań dodatkowych. Przedstawione $\mathrm{w}$ tym opracowaniu rozwiązania terapeutyczne nie stanowią rekomendacji żadnego konkretnego produktu lub producenta.

\section{KONFLIKT INTERESÓW}

Autorzy nie zgłaszają konfliktu interesów.

References

Piśmiennictwo

1. Knobler R., Moinzadeh P., Hunzelmann N., Kreuter A., Cozzio A., Mouthon L., et al.: European Dermatology Forum S1 guideline on the diagnosis and treatment of sclerosing diseases of the skin, Part 1: localized scleroderma, systemic sclerosis and overlap syndromes. J Eur Acad Dermatol Venereol 2017, 31, 1401-1424.

2. Kreuter A., Krieg T., Worm M., Wenzel J., Moinzadeh P., Kuhn A., et al.: German guidelines for the diagnosis and therapy of localized scleroderma. J Dtsch Dermatol Ges 2016, 14, 199-216.

3. Florez-Pollack S., Kunzler E., Jacobe H.T.: Morphea: current concepts. Clin Dermatol 2018, 36, 475-486.

4. Wolska-Gawron K., Krasowska D.: Localized scleroderma - classification and tools used for the evaluation of tissue damage and disease activity/severity. Dermatol Rev 2017, 104, 269-289.

5. Mertens J., Seyger M.M.B., Thurlings R.M., Radstake T.R.D.J., de Jong E.M.G.J.: Morphea and eosinophilic fasciitis: an update. Am J Clin Dermatol 2017, 18, 491-512.

6. Lis-Święty A., Skrzypek-Salamon A., Ranosz-Janicka I., Brzezińska-Wcisło L.: Localized scleroderma: clinical and epidemiological features with emphasis on adulthood- versus childhood-onset disease differences. J Eur Acad Dermatol Venereol 2017, 31, 1595-1603.

7. Dilia G., Michele C., Emanuele C., Amelia S., Federica L., Clodoveo F.: From localized scleroderma to systemic sclerosis: coexistence or possible evolution. Dermatol Res Pract 2018, 2018: 1284687.

8. Asano Y., Fujimoto M., Ishikawa O., Sato S., Jinnin M., Takehara K., et al.: Diagnostic criteria, severity classification and guidelines of localized scleroderma. J Dermatol 2018, 45, 755-780.

9. Saracino A.M., Denton C.P., Orteu C.H.: The molecular pathogenesis of morphoea: from genetics to future treatment targets. Br J Dermatol 2017, 177, 34-46.

10. Spalek M., Jonska-Gmyrek J., Gałecki J.: Radiation-induced morphea - a literature review. J Eur Acad Dermatol Venereol 2015, 29, 197-202.

11. Mattozzi C., Richetta A.G., Cantisani C., Giancristoforo S., D'Epiro S., Gonzalez Serva A., et al.: Morphea, an unusual side effect of anti-TNF-alpha treatment. Eur J Dermatol 2010, 20, 400-401.

12. Tuffanelli D.L., Winkelmann R.K.: Systemic scleroderma. A clinical study of 727 cases. Arch Dermatol 1961, 84, 359-371.

13. Peterson L.S., Nelson A.M., Su W.P.: Classification of morphea (localized scleroderma). Mayo Clin Proc 1995, 70, 1068-1076.

14. ZulianF., Athreya B.H., Laxer R., Nelson A.M., Feitosa de Oliveira S.K., Punaro M.G., et al.: Juvenile localized scleroderma: clinical and epidemiological features in 750 children. An international study. Rheumatology 2006, 45, 614-620.

15. Ross N.A., Lee J.B., Keller M.S.: Atrophoderma like guttate morphea. Cutis 2018, 102, 7-10.

16. Aranegui B., Jiménez-Reyes J.: Morfeaen la infancia: actualización. Actas Dermosifiliogr 2018, 109, 312-322.

17. Forsea A.M., Cretu A.N., Ionescu R., Giurcaneanu C.: Disabling pansclerotic morphea of childhood - unusual case and management challenges. J Med Life 2008, 1, 348-354. 
18. Schoch J.J., Schoch B.S., Werthel J.D., McIntosh A.L., Davis D.M.R.: Orthopedic complications of linear morphea: implications for early interdisciplinary care. Pediatr Dermatol 2018, 35, 43-46.

19. Merlin E., Breton S., Fraitag S., Stéphan J.L., Wouters C., Bodemer C., et al.: Fibrous arthropathy associated with morphea: anew cause of diffuse acquired joint contractures. Pediatrics 2017, 140, pii: e20161899.

20. Khamaganova I.: Progressive hemifacial atrophy and linear scleroderma en coup de sabre: a spectrum of the same disease? Front Med 2017, 4, 258.

21. Holland K.E., Steffes B., Nocton J.J., Schwabe M.J., Jacobson R.D., Drolet B.A.: Linear scleroderma en coup de sabre with associated neurologic abnormalities. Pediatrics 2006 117, 132-136.

22. Mears K.A., Servat J.J., Black E.H.: Linear scleroderma en coup de sabre affecting the upper eyelid and lashes. Graefe's Arch Clin Exp Ophthalmol 2012, 250, 1097-1099.

23. Gambichler T., Kreuter A., Hoffmann K., Bechara F.G., Altmeyer P., Jansen T.: Bilateral linear scleroderma en coup de sabre associated with facial atrophy and neurological complications. BMC Dermatol 2001, 1, 9.

24. Kreuter A., Mitrakos G., Hofmann S., Lehmann P., Sticherling M., Krieg T., et al.: Localized scleroderma of the head and face area: a retrospective cross-sectional study of 96 patients from 5 German tertiary referral centres. Acta Derm Venereol 2018, 98, 603-605.

25. Fain E.T., Mannion M., Pope E., Young D.W., Laxer R.M., Cron R.Q.: Brain cavernomas associated with en coup de sabre linear scleroderma: two case reports. Pediatr Rheumatol Online J 2011, 9, 18.

26. Allmendinger A., Ricci J., Desai N., Viswanadhan N., Rodriguez D.: Atypical neuroimaging manifestations of linear scleroderma en coup de sabre. Iran J Child Neurol 2015, 9, 62-68.

27. Al-Aizari N.A., Azzeghaiby S.N., Al-Shamiri H.M., Darwish S., Tarakji B.: Oral manifestations of Parry-Romberg syndrome: a review of literature. Avicenna J Med 2015, 5, 25-28.

28. Tolkachjov S.N., Patel N.G., Tollefson M.M.: Progressive hemifacial atrophy: a review. Orphanet J Rare Dis $2015,10,39$.

29. Fea A.M., Aragno V., Briamonte C., Franzone M., Putignano D., Grignolo F.M.: Parry Romberg syndrome with a wide range of ocular manifestations: a case report. BMC Ophthalmol 2015, 15, 119.

30. Aydın H., Yologlu Z., Sargın H., Metin R.: Parry-Romberg syndrome. Physical, clinical, and imaging features. Neurosciences 2015, 20, 368-371.

31. Guerrerosantos J., Guerrerosantos F., Orozco J.: Classification and treatment of facial tissue atrophy in Parry-Romberg disease. Aesthetic Plast Surg 2007, 31, 424-434.

32. Constantin T., Foeldvari I., Pain C.E., Pálinkás A., Höger P., Moll M., et al.: Development of minimum standards of care for juvenile localized scleroderma. Eur J Pediatr 2018, 177, 961-977.

33. Abbas O, Bhawan J.: Sclerosing disorders of the skin: an overview with focus on histopathological features. Am J Dermatopathol 2014, 36, 763-780.

34. Arkachaisri T., Vilaiyuk S., Li S., O'Neil K.M., Pope E., Higgins G.C., et al.: The localized scleroderma skin severity index and physician global assessment of disease activity: a work in progress toward development of localized scleroderma outcome measures. J Rheumatol 2009, 36, 2819-2829.

35. Arkachaisri T., Vilaiyuk S., Torok K.S., Medsger T.A.: Development and initial validation of the localized scleroderma skin damage index and physician global assessment of disease damage: a proof-of-concept study. Rheumatology 2010, 49, 373-381.

36. Skrzypek-Salamon A., Lis-Święty A., Ranosz-Janicka I., Brzezińska-Wcisło L.: Localized scleroderma assessement tool (LoSCAT) adapted for us in adult patients: report from an initial validation study. Health Qual Life Outcomes 2018, 16, 185-192.

37. Wolska-Gawron K., Michalska-Jakubus M., Krasowska D.: Localized scleroderma - current treatment options. Dermatol Rev 2017, 104, 606-618.

38. Poff S., Li S.C., Kelsey C.E., Foeldvari I., Torok K.S.: Durometry as an outcome measure in juvenile localized scleroderma. Br J Dermatol 2016, 174, 228-230.

39. Li S.C., Liebling M.S., Haines K.A.: Ultrasonography is a sensitive tool for monitoring localized scleroderma. Rheumatol 2007, 46, 1316-1319

40. Shaw L.J., Shipley J., Newell E.L., Harris N., Clinch J.G., Lovell C.R.: Scanning laser Doppler imaging may predict disease progression of localized scleroderma in children and young adults. Br J Dermatol 2013, 169, $152-155$.

41. Kroft E.B.M., Groeneveld T.J., Seyger M.M.B., de Jong E.M.G.J.: Efficacy of topical tacrolimus $0.1 \%$ in active plaque morphea: randomized, double-blind, emollient-controlled pilot study. Am J Clin Dermatol 2009, 10, $181-187$.

42. Wat H., Dytoc M.: Off-label uses of topical vitamin D in dermatology: a systematic review. J Cutan Med Surg 2014, $18,91-108$.

43. York N.R., Jacobe H.T.: UVA1 phototherapy: a review of mechanism and therapeutic application. Int J Dermatol 2010, 49, 623-630.

44. Buense R., Duarte I.A.G., Bouer M.: Localized scleroderma: assessment of the therapeutic response to phototherapy. An Bras Dermatol 2012, 87, 63-69.

45. Wen X., Li Y., Hamblin M.R.: Photodynamic therapy in dermatology beyond non-melanoma cancer: an update. Photodiagn Photodyn Ther 2017, 19, 140-152.

46. Gordon Spratt E.A., Gorcey L.V., Soter N.A., Brauer J.A.: Phototherapy, photodynamic therapy and photophoresis in the treatment of connective-tissue diseases: a review. Br J Dermatol 2015, 173, 19-30.

47. Mertens J., Reek J., Kievit W., Kerkhof P., Thurlings R., Radstake T., et al.: Drug survival and predictors of drug survival for methotrexate treatment in a retrospective cohort of adult patients with localized scleroderma. Acta DermVenereol 2016, 96, 943-947.

48. Zulian F.: Scleroderma in children. Best Pract Res Clin Rheumatol 2017, 31, 576-595.

49. Martini G., Ramanan A.V., Falcini F., Girschick H., Goldsmith D.P., Zulian F.: Successful treatment of severe or methotrexate-resistant juvenile localized scleroderma with mycophenolate mofetil. Rheumatology 2009, 48, 1410-1413.

50. Wen W.X., Lee S.Y., Siang R., Koh R.Y.: Repurposing pentoxifylline for the treatment of fibrosis: an overview. Adv Ther 2017, $34,1245-1269$ 
51. Sicińska J., Rudnicka L.: Current treatment of systemic sclerosis. Part II. Vascular and antifibrotic treatment. Pol Merkuriusz Lek 2008, 25, 196-200.

52. Sosińska P., Baum E., Maćkowiak B., Maj M., Sumińska-Jasińska K., Staniszewski R., et al.: Sulodexide reduces the proinflammatory effect of serum from patients with peripheral artery disease in human arterial endothelial cells. Cell Physiol Biochem 2016, 40, 1005-1012.

53. Krasowska D., Polkowska-Pruszyńska B., Michalak-Stoma A.: Sulodeksyd - możliwości zastosowania w dermatologii. Dermatol Rev 2019, 106, 52-70.

54. Połubińska A., Staniszewski R., Baum E., Sumińska-Jasińska K., Bręborowicz A.: Sulodexide modifies intravascular homeostasis what affects function of the endothelium. Adv Med Sci 2013, 58, 304-310.

55. Bali G., Frühauf J., Wutte N., Aberer E.: Cyclosporine reduces sclerosis in morphea: a retrospective study in 12 patients and a literature review. Dermatology 2016, 232, 503-510.

56. Rudolph R.I., Leyden J.J.: Physiatrics for deforming linear scleroderma. Arch Dermatol 1976, 112, 995-997.

57. Górkiewicz-Petkow A., Kalinska-Bienias A.: Systemic involvement in localized scleroderma/morphea. Clin Dermatol 2015, 33, 556-562.

58. Backa T., Zoto A., Rapushi E., Ktona E., Ylli Z., Tanka M.: Pulmonary involvement in patient diagnosed with morphea. Ann Rheum Dis 2015, 74, 1142-1143.

Received: 27.06 .2019

Accepted: 21.07.2019

Otrzymano: $27.06 .2019 \mathrm{r}$

Zaakceptowano: 21.07.2019 r. 